\title{
Statistical Analysis and Mathematical Modeling of a Tracer Test on the Santa Clara River, Ventura County, California
}

By Katherine Schipke Paybins, Tracy Nishikawa, John A. Izbicki, and Eric G. Reichard

\section{U.S. GEOLOGICAL SURVEY}

Water-Resources Investigations Report 97-4275

Prepared in cooperation with the

UNITED WATER CONSERVATION DISTRICT

हి

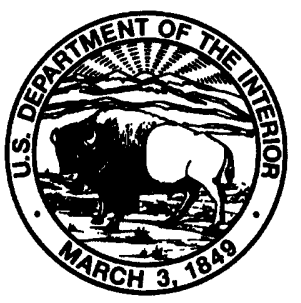




\title{
U.S. DEPARTMENT OF THE INTERIOR BRUCE BABBITT, Secretary
}

\author{
U.S. GEOLOGICAL SURVEY
}

Thomas J. Casadevall, Acting Director

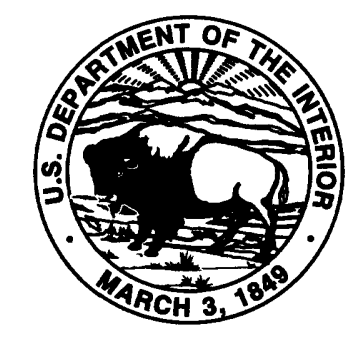

The use of firm, trade, and brand names in this report is for identification purposes only and does not constitute endorsement by the U.S. Geological Survey.

For additional information write to:

Copies of this report can be purchased from:

District Chief

U.S. Geological Survey

Placer Hall, Suite 2012

$6000 \mathrm{~J}$ Street

Sacramento, CA 95819-6129
U.S. Geological Survey

Information Services

Box 25286

Federal Center

Denver, CO 80225 


\section{CONTENTS}

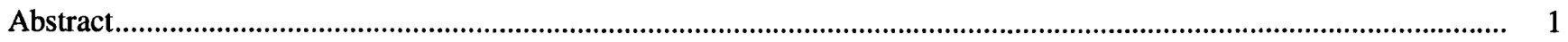

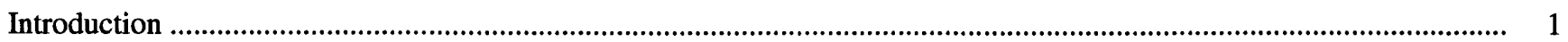

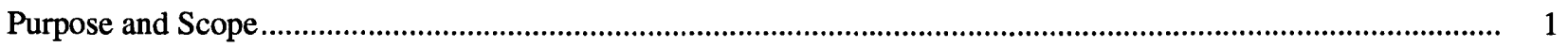

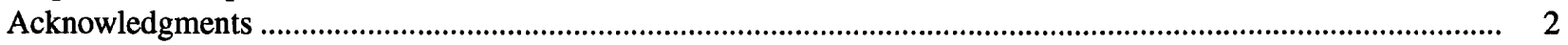

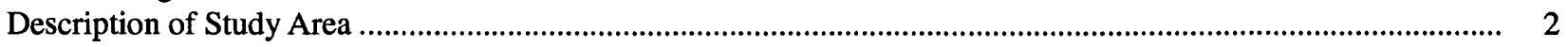

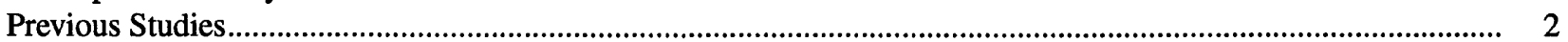

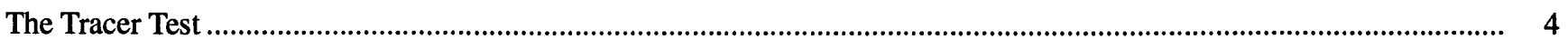

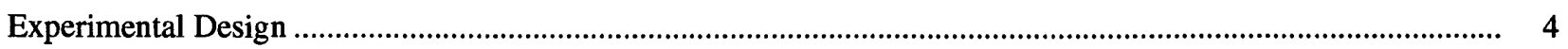

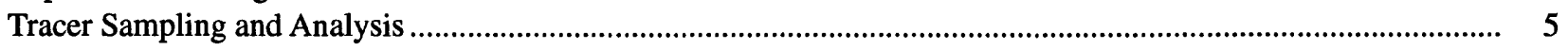

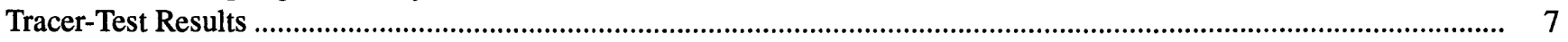

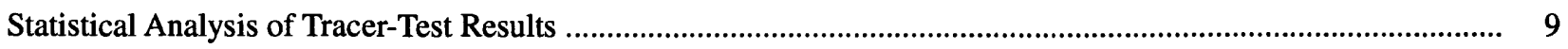

Numerical Models Used to Evaluate the Tracer-Test Results ................................................................................ 11

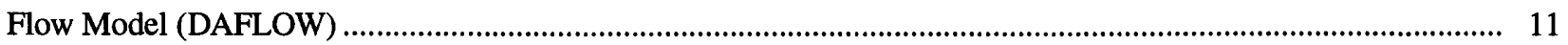

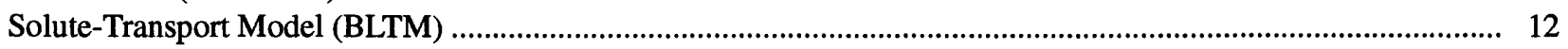

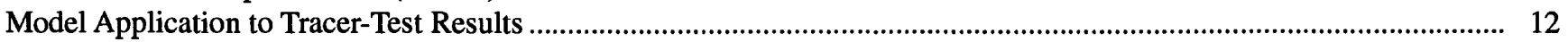

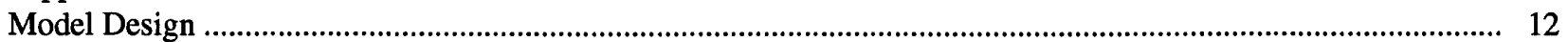

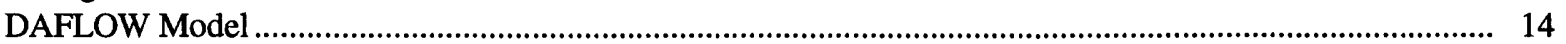

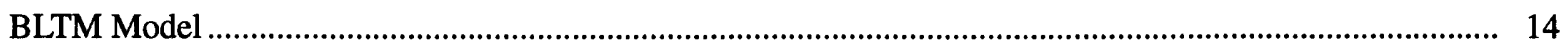

Parameter Starting Estimates for DAFLOW and BLTM ........................................................................ 14

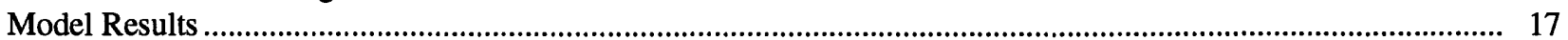

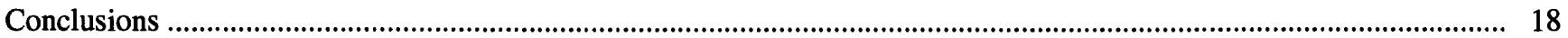

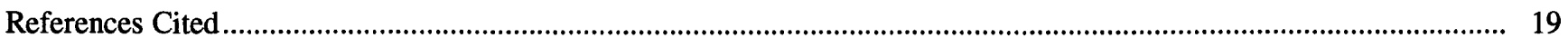

\section{FIGURES}

1. Map showing location of study area and surface-water sampling sites along Piru Creek and the Santa Clara River, Ventura County, California.....

2. Photograph showing the dye sampling procedure at the Piru Creek sampling site (site 1),

Piru Creek basin, Ventura County, California ....

3. Photograph showing the automated sampling setup at the Torrey Road sampling site (site 2),

Santa Clara River Basin, Ventura County, California.

4. Graph showing the relation between dye concentration and time at the five sampling sites on the

Santa Clara River, Ventura County, California

5-7. Graphs showing:

5. Relation of unit-peak concentration to peak traveltime .............................................................................. 10

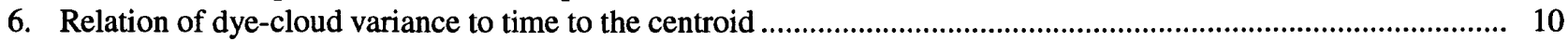

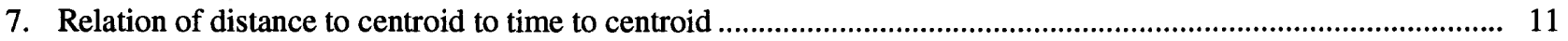

8. Schematic showing division of the study area into branches and grid points for application of the flow and solute-transport models

9-12. Graphs showing relation of drainage area to discharge, and relation of stream width to discharge for:

9. Piru Creek.

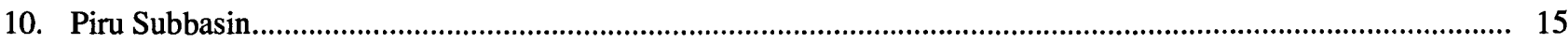

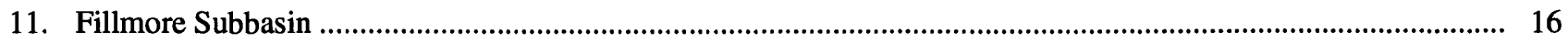

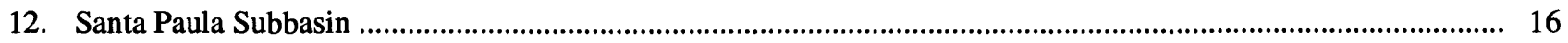

13. Graph showing measured and model-simulated dye concentration at sites 2-6 on the Santa Clara River during the 24- hour test, Ventura County, California 


\section{TABLES}

1. Statistics from the time-concentration curves, Santa Clara River, October 1994 ...................................................... 9

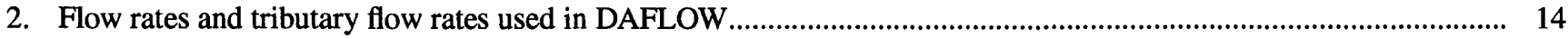

3. Initial hydraulic geometry parameters for the flow model (DAFLOW) ................................................................. 15

4. Final parameter estimates for DAFLOW and BLTM, Ventura County, California ................................................. 16

5. Measured and model-simulated mass, time-to-peak, and peak concentration values for sites 2-6 on the Santa Clara River

\section{CONVERSION FACTORS, VERTICAL DATUM, AND ABBREVIATIONS}

\begin{tabular}{rcl}
\hline Mult/ply & By & To obtaln \\
\hline acre-foot per year (acre-ft/yr) & 1,233 & cubic meter per year \\
cubic foot $\left(\mathrm{ft}^{3}\right)$ & 0.02832 & cubic meter \\
cubic foot per second $\left(\mathrm{ft}^{3} / \mathrm{s}\right)$ & 0.02832 & cubic meter per second \\
foot $(\mathrm{ft})$ & 0.3048 & meter \\
foot per second $(\mathrm{ft} / \mathrm{s})$ & 0.3048 & meter per second \\
inch $(\mathrm{in})$. & 25.4 & millimeter \\
mile $(\mathrm{mi})$ & 1.609 & kilometer \\
pound $(\mathrm{lb})$ & 0.4536 & kilogram \\
square mile $\left(\mathrm{mi}^{2}\right)$ & 2.590 & square kilometer \\
\hline
\end{tabular}

Temperature is given in degrees Fahrenheit $\left({ }^{\circ} \mathrm{F}\right)$, which can be converted to degrees Celsius $\left({ }^{\circ} \mathrm{C}\right)$ by the following equation:

$$
{ }^{\circ} \mathrm{F}=1.8\left({ }^{\circ} \mathrm{C}\right)+32
$$

\section{VERTICAL DATUM}

Sea level: In this report, "sea level" refers to the National Geodetic Vertical Datum of 1929 (NGVD of 1929) - a geodetic datum derived from a general adjustment of the firstorder level nets of both the United States and Canada, formerly called Sea Level Datum of 1929.

\section{ABBREVIATIONS}

BLTM a one-dimensional solute-transport model (Jobson and Schoellhamer, 1993)

DAFLOW a one-dimensional surface-water flow model (Jobson, 1989)

hr hour

$\mathrm{kg} \quad$ kilogram

L liter

$\mu \mathrm{g} / \mathrm{L} \quad$ microgram per liter

ppb parts per billion

USGS U.S. Geological Survey

UWCD United Water Conservation District

Concentrations of chemical constituents in water are given in micrograms per liter $(\mu \mathrm{g} / \mathrm{L})$, approximately equivalent to parts per billion. 


\title{
Statistical Analysis and Mathematical Modeling of a Tracer Test on the Santa Clara River, Ventura County, California
}

\author{
By Katherine Schipke Paybins, Tracy Nishikawa, John A. Izbicki, and Eric G. Reichard
}

\section{ABSTRACT}

To better understand flow processes, solutetransport processes, and ground-water/surfacewater interactions on the Santa Clara River in Ventura County, California, a 24-hour fluorescent-dye tracer study was performed under steady-state flow conditions on a 28 -mile reach of the river.

The study reach includes perennial (uppermost and lowermost) subreaches and ephemeral subreaches of the lower Piru Creek and the middle Santa Clara River. Dye was injected at a site on Piru Creek, and fluorescence of river water was measured continuously at four sites and intermittently at two sites. Discharge measurements were also made at the six sites. The time of travel of the dye, peak dye concentration, and time-variance of time-concentration curves were obtained at each site. The long tails of the time-concentration curves are indicative of sources/sinks within the river, such as riffles and pools, or transient bank storage. A statistical analysis of the data indicates that, in general, the transport characteristics follow Fickian theory.

These data and previously collected discharge data were used to calibrate a onedimensional flow model (DAFLOW) and a solutetransport model (BLTM). DAFLOW solves a simplified form of the diffusion-wave equation and uses empirical relations between flow rate and cross-sectional area, and flow rate and channel width. BLTM uses the velocity data from DAFLOW and solves the advection-dispersion transport equation, including first-order decay.
The simulations of dye transport indicated that (1) ground-water recharge explains the loss of dye mass in the middle, ephemeral, subreaches, and (2) ground-water recharge does not explain the loss of dye mass in the uppermost and lowermost, perennial, subreaches. This loss of mass was simulated using a linear decay term. The loss of mass in the perennial subreaches may be caused by a combination of photodecay or adsorption/desorption.

\section{INTRODUCTION}

\section{Purpose and Scope}

The U.S. Geological Survey (USGS), in cooperation with the United Water Conservation District (UWCD), completed a 24-hour tracer study on the Santa Clara River in Ventura County, California, October 25-26, 1994. The dye-tracer study was designed to quantify recharge/discharge relations, to obtain traveltime data, and to calibrate flow and solutetransport models. Typically, dye-tracer studies have been done on perennial streams in the Midwestern and Eastern United States (for example, Nordin and Sabol, 1974), and the authors believe that this test is one of the first to be performed on a stream with ephemeral subreaches in the Western United States. This report consists of a description of the method of the tracer test, descriptive and statistical analyses of the data, and modeling results using these data. The velocity and concentration measurements were used to calibrate two one-dimensional models: a flow model, DAFLOW, and a solute-transport model, BLTM, (Jobson, 1989; Jobson and Schoellhamer, 1993). 
The dye-tracer study was part of a larger USGS study of surface-water/ground-water interactions in the Santa Clara River Valley. The Santa Clara River is the principal source of recharge to ground water in the valley and in the Oxnard Plain. The UWCD operates two major surface-water facilities in the Santa Clara Valley: Santa Felicia Dam on Piru Creek is used for storage in Lake Piru and release to the Santa Clara River, and the Freeman Dam and Diversion at the lower end of the Santa Clara Valley is used to divert water to Oxnard Plain for ground-water recharge and direct surface-water delivery.

\section{Acknowledgments}

The authors thank the United Water Conservation District personnel for their support of this project. The authors also gratefully acknowledge the assistance of Steven Crawford, Michael Land, and Jill Densmore of the USGS in the manual sampling, and Bob Taylor, also of the USGS, who performed the stream-discharge measurements at all the sites. Without these people this project could not have been successfully completed.

\section{Description of Study Area}

The lower Santa Clara River Valley is in the Santa Clara-Calleguas Hydrologic Unit in Ventura County, southern California (fig. 1). From the Los Angeles County line to the Pacific Ocean, the river flows through agricultural fields and small urban communities in the valley. The study area consists of a 28mile reach of the Santa Clara River system, and includes Piru Creek, downstream from Santa Felicia Dam on Lake Piru, and the Santa Clara River from Piru Creek downstream to Freeman Diversion (fig. 1). The study reach includes perennial (uppermost and lowermost) subreaches and ephemeral subreaches of the lower Piru Creek and the middle Santa Clara River (Reichard and others, USGS, written commun., 1997). Perennial flow in the river is maintained by releases from Santa Felicia Dam, by sewage effluent, and by ground-water discharge. The river channel is sandy and braided.

From Santa Felicia Dam, water is released to Piru Creek, which is a tributary of the Santa Clara River. Releases from the dam control the flow in the Santa Clara River in nonstorm periods. Generally, the dam is operated to collect water in Lake Piru in wet months (primarily winter) and release water to Santa Clara River in dry months. The controlled releases typically range from 100 to $350 \mathrm{ft}^{3} / \mathrm{s}$.

The ground-water system in the Santa Clara River Valley consists of three ground-water subbasins-Piru, Fillmore, and Santa Paula-whose areas are about 11,30 , and $20 \mathrm{mi}^{2}$, respectively. The subbasins are composed of alluvium of Holocene age that ranges in thickness from 150 to $400 \mathrm{ft}$ and underlying older marine and continental deposits that are as much as 6,000 $\mathrm{ft}$ thick (Densmore and others, 1992). The main source of recharge to the aquifers is infiltration of streamflow from the Santa Clara River and its tributaries. Total water use in the three subbasins is approximately 90,000 acre-ft/yr, most of which is ground water.

Regular measurements of discharge and water quality have been made at 25 locations along the Santa Clara River and its tributaries for the past several years (Reichard and others, USGS, written commun., 1997). Four of the sites are USGS long-term continuousrecord gaging stations. The other sites are miscellaneous-measurement stations chosen specifically for this and a previous USGS study (Densmore and others, 1992). Generally, these data indicate that flow loss to ground-water recharge, diversions, and evapotranspiration occurs throughout most of the Piru Subbasin and the upstream part of the Fillmore Subba$\sin$. Outflows from ground-water discharge occur at the Piru Narrows between the Piru and Fillmore Subbasins and at the Fillmore Narrows between the Fillmore and Santa Paula Subbasins (fig. 1).

\section{Previous Studies}

Surface-water tracer tests traditionally have been used to ascertain the flow characteristics (such as discharge) or to calibrate models of streams and rivers (for example, Ishii and Wilder, 1993; Kilpatrick and Cobb, 1985). Tracer tests also have been used to ascertain the transport characteristics, such as traveltime, peak concentration, and longitudinal dispersion, and interaction with the hyporheic zone of streams and rivers (Broshears and others, 1993; Graf, 1995; Harvey and others, 1996; Jobson, 1987, 1996; Kilpatrick and Wilson, 1989; Turner, 1994). The hyporheic zone is the nearsurface zone where small-scale (centimeter to meter) exchanges of water occur between the channel and the subsurface. 


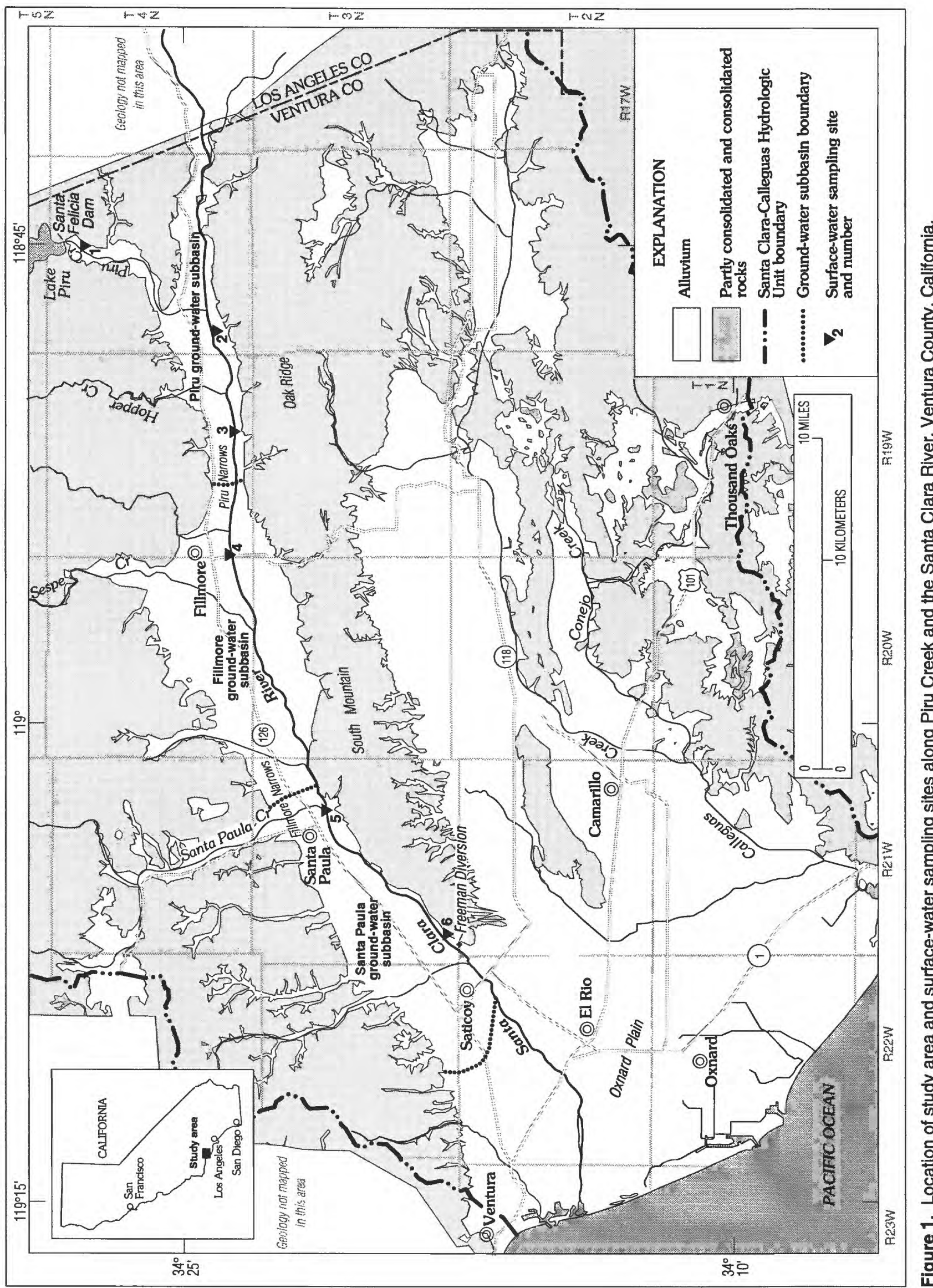


Kilpatrick and Wilson (1989) and Wilson and others (1986) recommend the use of rhodamine WT as the tracer and emphasize the need for careful design of tracer studies. They describe the field methodology required to use dye tracers to estimate the time of travel of a stream. The resulting traveltime-distance curves can be used to estimate the time required for a solute to pass through the study reach.

Jobson (1987) developed and applied onedimensional flow and solute-transport models to four rivers under different flow conditions to estimate the longitudinal dispersion and first-order decay coefficients. He outlines a systematic parameter estimation of procedure for the solute-transport models. His model-derived estimates of the dispersion coefficient are comparable to estimates made on the basis of analytic solutions but are generally less than values estimated using the method of moments.

Nordin and Sabol (1974) statistically analyzed data from 51 tracer experiments performed on rivers primarily located in the Midwestern and Eastern United States. Their goal was to ascertain if the longitudinal dipersion processes in these rivers follow one-dimensional, Fickian-type diffusion theory using empirical relations. A river is Fickian if the transport processes in the river follow the convection-dispersion equation. They developed statistical relations between traveltime, peak concentration, travel distance and variance in time and distance of the dye plumes. These equations are discussed more fully later in this report.

Harvey and others (1996) used subreach-scale measurement of hydraulic heads and hydraulic conductivity to compute streambed fluxes (hydrometric approach) in order to determine the reliability of the stream tracer approach in characterizing hyporheic exchange. They found that the stream tracer approach was more reliable at characterizing subsurface exchanges at lower baseflow and rapid exchange (that is, time scale of hours) between the stream and its gravel bed than was the subreach-scale measurement of hydraulic heads and hydraulic conductivity to compute streambed fluxes (the hydrometric approach).

Jobson (1996) used empirical relations to estimate unit peak concentration, time of travel of peak concentration, time of travel of the leading edge, and time of passage. He applied these relations to data collected from 60 rivers and found that unit peak concentration was well correlated with traveltime of the peak concentration. Traveltime of unit peak concentration was calculated on the basis of the highest probable velocity of the unit peak concentration, which in turn is a function of drainage area, flow rate, and reach slope. Jobson also found that traveltime of the leading edge was about 89 percent of the traveltime of the unit peak concentration.

Densmore and others (1992) studied the Santa Clara River to determine the effects of three different release rates of water from Lake Piru on water quality and on ground-water recharge in the three subbasins. The study was done during a drought period (1987-92) when base flow in the river occurred solely in the reach between the lower Fillmore Subbasin and the Freeman Diversion (fig. 1). The results of that study showed that at three different rates of release from the dam $(100$, 272 , and $391 \mathrm{ft}^{3} / \mathrm{s}$ ), most of the recharge occurred in the Piru and Fillmore Subbasins and water quality degraded in the Santa Paula Subbasin because of the discharge of high-sulfate ground water to the Santa Clara River at the Fillmore Narrows. The $391-\mathrm{ft}^{3} / \mathrm{s}$ release was found to be the most efficient rate both to recharge the ground-water subbasins and to deliver water to the Freeman Diversion.

\section{THE TRACER TEST}

\section{Experimental Design}

A fluorescent dye, rhodamine WT, was introduced into Piru Creek at the Santa Felicia Dam, and dye concentration was measured at six sites over a 28mile reach of Piru Creek and the Santa Clara River from the Santa Felicia Dam on Lake Piru to Freeman Diversion (fig. 1). Standard methods of estimation of dye dosage, sampling, and laboratory analysis of dye samples were used in this study (Kilpatrick and Wilson, 1989; Wilson and others, 1986). Continuous data were collected using a flowthrough apparatus on a fluorometer at four sites: Torrey Road (site 2), Chambersburg Road (site 4), South Mountain Road (site 5), and Freeman Diversion (site 6). Intermittent samples were collected manually at three sites: Piru Creek (site 1), Torrey Road (site 2), and Cavin Road (site 3). The six sites were chosen on the basis of their location in relation to the ground-water subbasin narrows, accessibility, and (or) proximity to the initial dye-injection point (fig. 1).

The slug-injection method was used to introduce the dye into the flow (Kilpatrick and Cobb, 1985; Kilpatrick and Wilson, 1989; Wilson and others, 1986). 
This method is relatively simple, and it allows for the tracking of a singular cloud of dye as it moves downstream. The dye in the slug-injection method is added to the flow at one time only. The peak dye concentration, using the slug-injection method, is additive; therefore, a single response curve can be obtained at each site as the dye moves downstream.

It is USGS policy to keep peak dye concentration below $10 \mathrm{ppb}$ at any water-withdrawal points. There are no water-withdrawal points for direct human consumption between the input site on Piru Creek and Freeman Diversion (site 6). The flow diversion for ground-water recharge in the Piru subbasin was shut off during the test. Because the Freeman Diversion to ground-water recharge was in operation during the test, however, concentrations were planned to be at or below the standard by the time the dye reached the diversion.

The mass of dye to be injected into the flow was calculated on the basis of pre-set sampling thresholds of the fluorometers. In order to stay within the linear range of the fluorometer, the maximum allowable value at the first automated sampling point (site 2) was 100 $\mu \mathrm{g} / \mathrm{L}(100 \mathrm{ppb})$. The dye mass for injection was calculated using the formula of Kilpatrick and Wilson (1989):

$$
\left.V_{s}=3.4 \times 10^{-4} \times Q L / v\right)^{0.94} \times C_{p}
$$

where

$V_{s}$ is the volume of 20-percent stock solution rhodamine WT dye, in liters,

$Q$ is the stream discharge, in cubic feet per second,

$L$ is the length of the measurement subreach in miles,

$v$ is the mean stream velocity, in feet per second, and

$C_{p}$ is the peak concentration at the sampling site, in micrograms per liter.

For this equation, $v$ was estimated to be $3.0 \mathrm{ft} / \mathrm{s}$; $Q$ was estimated to be $225 \mathrm{ft}^{3} / \mathrm{s} ; L$, between sites 1 and 2 was $6.3 \mathrm{mi}$; and $\mathrm{C}_{\mathrm{p}}$ was estimated to be $100 \mu \mathrm{g} / \mathrm{L}$. Thus, the quantity of dye necessary for this test $\left(\mathrm{V}_{\mathrm{s}}\right)$ was calculated to be 11.1 liters, or $2.26 \mathrm{~kg}$ of dye. The expected values of $C_{p}$ at the downstream sites were: Chambersburg Road (site 4), $47.52 \mu \mathrm{g} / \mathrm{L}$; South Mountain Road (site 5), $30.38 \mu \mathrm{g} / \mathrm{L}$; and Freeman Diversion, (site 6) $24.75 \mu \mathrm{g} / \mathrm{L}$. The sites used in the calculation of the expected peak concentration $(C p)$ are the following distances downstream from the Santa Felicia Dam on Lake Piru: Torrey Rd. (site 2) $6.34 \mathrm{mi}$; Chambersburg Rd. (site 4) $13.90 \mathrm{mi}$; South Mountain Rd. (site 5) $22.37 \mathrm{mi}$; and Freeman Diversion (site 6) $27.79 \mathrm{mi}$.

The outflow from Santa Felicia Dam is located at the base of the dam, where the water is turbulent and the channel is lined with many large boulders. Downstream from the dam, Piru Creek is narrow and deep. The combination of these factors ensured good lateral mixing of the dye, a critical element in the sampling design. At the Piru and the Torrey Road sites (sites 1 and 2), depth-integrated, equal-width increment samples were collected to verify that the dye was completely mixed in the flow.

The release rate from the dam was held constant at about $170 \mathrm{ft}^{3} / \mathrm{s}$ for a few days prior to and during the dye study. Note that this flow rate is less than that $(225$ $\mathrm{ft}^{3} / \mathrm{s}$ ) assumed above. The implication of this difference is discussed below. Independent flow measurements were made at each sampling site on the day before and the day of the dye release. There were no measurable inflows from any of the tributaries to the Santa Clara River, and only one diversion was known to be in operation: the Golf Course diversion of about $8 \mathrm{ft}^{3} / \mathrm{s}$ located just upstream from South Mountain Road (site 5). The flow rate of the diversion was not measured directly, but it was estimated on the basis of independent flow measurements above and below the diversion.

\section{Tracer Sampling and Analysis}

At the Piru site (site 1), depth-integrated samples were collected using the equal-discharge-increment methodology; at Torrey Road and Cavin Road (sites 2 and 3), depth-integrated samples were collected using the equal-width-increment methodology (Guy and Norman, 1970; Edwards and Glysson, 1988). The Piru site (site 1) is approximately $600 \mathrm{ft}$ downstream from the dye-injection point. Samples at this site were collected every 2 to 5 minutes, the sampling rate decreasing as the dye cloud passed (fig. 2). At this site, it was expected that the total dye mass would be measured, establishing the baseline for the downstream sampling. The Torrey Road and the Cavin Road sites (2 and 3) were sampled at 1-meter intervals across the river every 5 minutes. Manual samples collected at Torrey Road (site 2), simultaneously with automatic sampling, indicated consistency between the two methods. All manual samples were stored in amber glass bottles, and dye concentration was analyzed in the lab. 


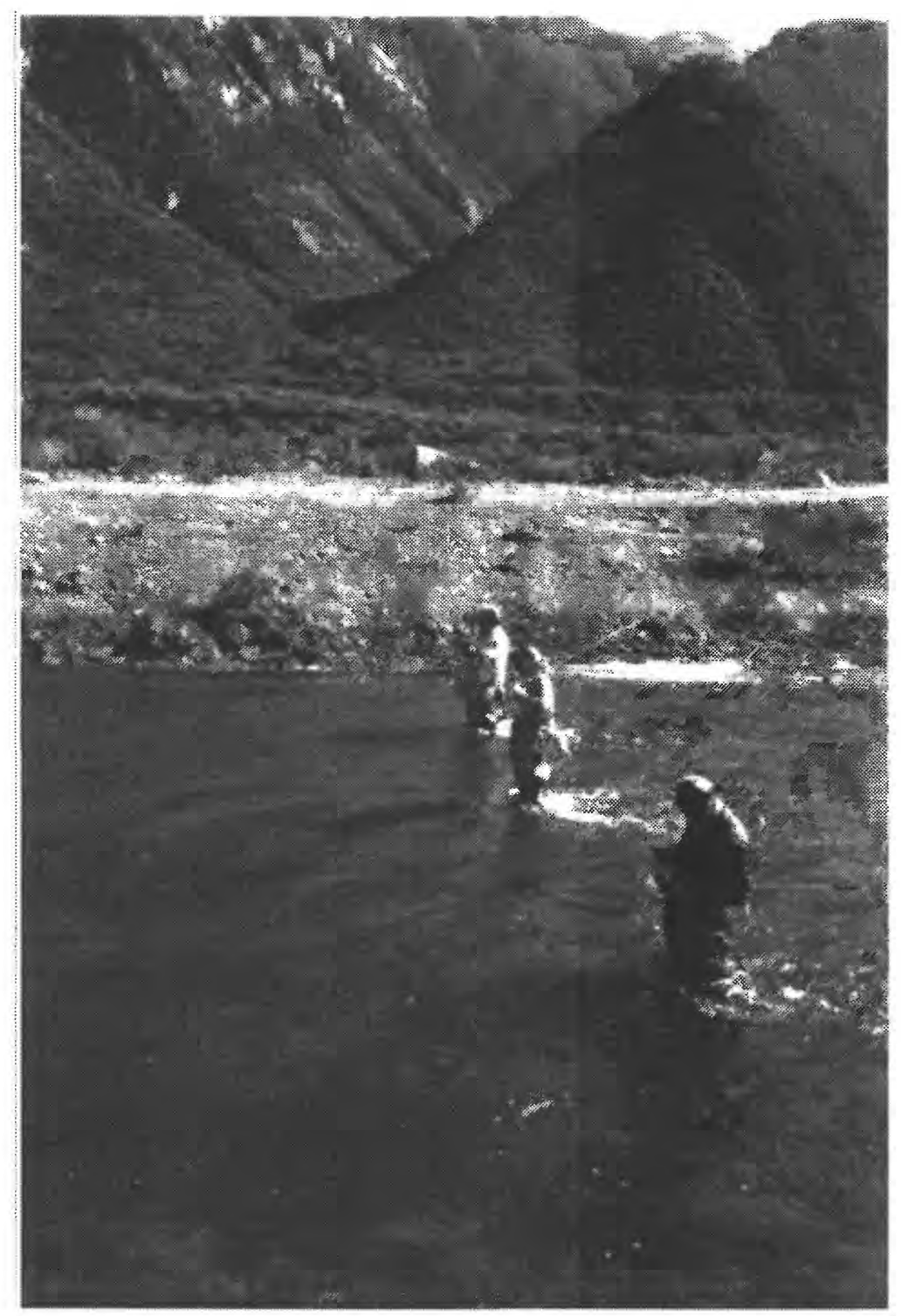

Figure 2. Dye-sampling procedure used at the Piru Creek sampling site (site 1), Piru Creek basin, Ventura County, California.

The sites at Torrey Road, Chambersburg Road, South Mountain Road, and Freeman Diversion (sites 2, 4,5 , and 6, respectively) were monitored continuously, beginning prior to the dye arrival and continuing until the level of fluorescence recorded in samples was approximately the same as the pre-test level. Dye arrival times were estimated on the basis of the assumed velocity of streamflow. Automatic sampling was needed because the slug-injection method requires that the entire time-concentration curve (changes in dye concentration through time) be well defined; when the dye concentration changes rapidly, the stream must be sampled at intervals of less than 1 minute (Kilpatrick and Cobb, 1985). At Torrey Road, Chambersburg Road, and South Mountain Road (sites 2, 4, and 5), water was pumped for automated sample collection from the center of flow in the stream channel through copper tubing to a fluorometer. The gas-operated piston pump was powered by nitrogen tanks. At Freeman Diversion (site 6), the automated sampling of water in the diversion canal was accomplished with a centrifugal pump. The maximum dye concentration was estimated before the test, and the fluorometer at each site was calibrated for that estimated peak value. The fluorometer was set up for flowthrough sampling and was connected to a data logger, a printer, and a computer (fig. 3). The data logger was programmed to record fluorescence, temperature, and time of the sample. Thus, sampling was 


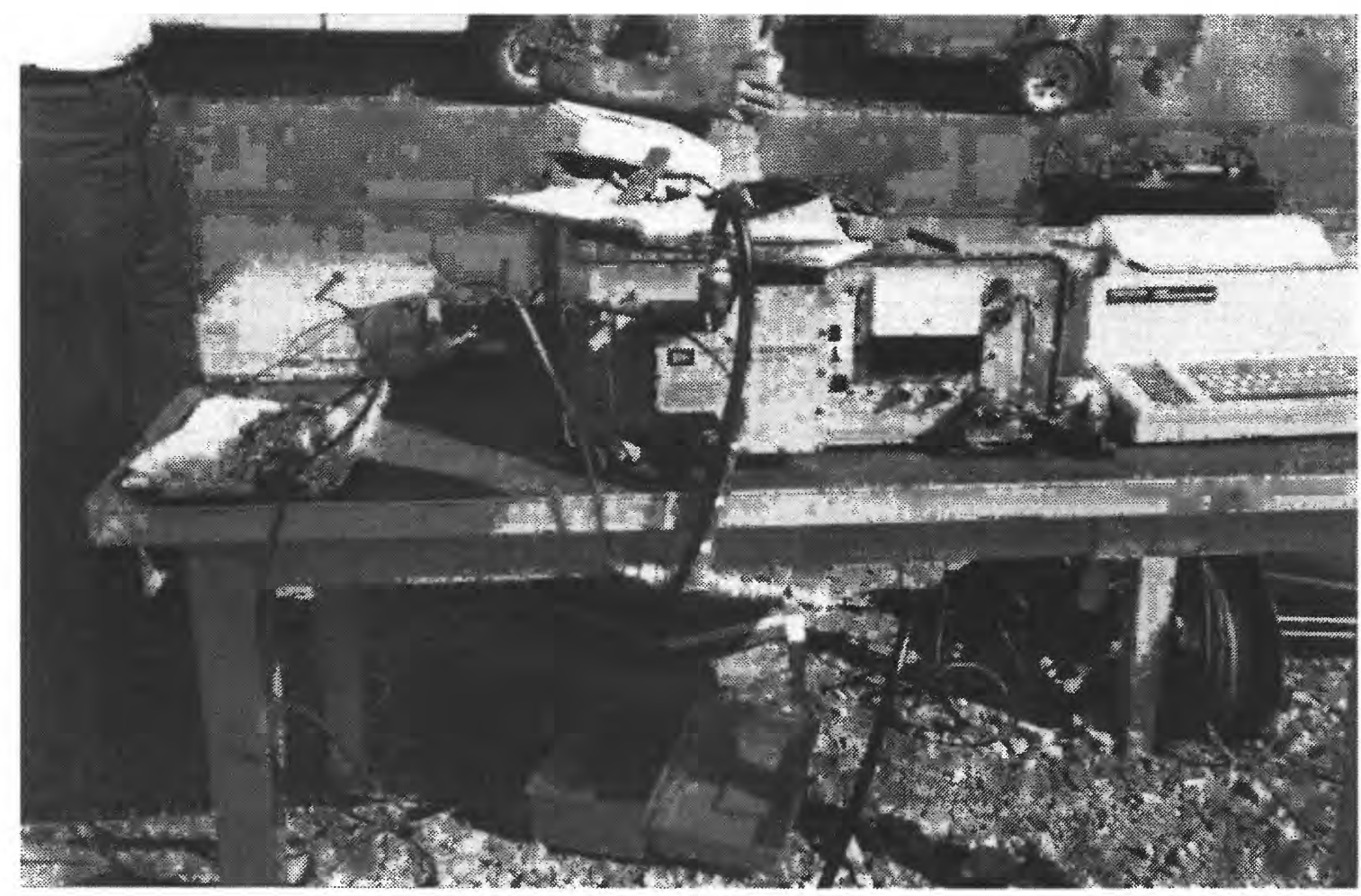

Figure 3. The automated sampling setup at the Torry Road sampling site (site 2), Santa Clara River basin, Ventura County, California.

maximized during periods of rapid change in concentration. The scale of measurement was changed as needed as the dye peak passed, and the data from the data logger LED screen were recorded by hand. Dye concentrations were later corrected for temperature effects.

\section{TRACER-TEST RESULTS}

The time-concentration data are presented in figure 4 and summarized in table 1 . Dye mass for each curve was calculated by numerically integrating the area under each curve. The elongated tail of the dyeconcentration curves in figure 4 is characteristic of natural streams, and is due to transient bank storage and (or) riffles and pools (Harvey Jobson, USGS, written commun., 1997). Peak concentrations $\left(C_{p}\right)$ were higher at sites 2 and 4 than expected because actual flow was lower than the flow used in pre-test calculations for estimating concentrations. Also, the initial calculations over-predicted the peak dye concentration at the sites farthest downstream (sites 5 and 6) because of the unexpected loss of dye mass in the upper reach of the test (sites 1 and 2), and because of dilution resulting from upwelling of ground water at the Fillmore Narrows.

The flow data shown in table 1 were rated by the USGS as good (within 10 percent of true values) to fair (within 15 percent), implying that some of the apparent changes in flow shown in table 1 may be caused by errors in flow measurement (R.H. Taylor, USGS, written commun., 1994). However, measurements of discharge in these reaches of Piru Creek and the Santa Clara River have been made repeatedly for several years, and the pattern and magnitude of increases and decreases in flow during this study generally are consistent with previous observations (E.G. Reichard and others, USGS, written commun., 1997).

The dye mass collected in manual sampling at Piru (site 1) was calculated to be $2.48 \mathrm{~kg}$, suggesting that manual sampling techniques were adequate to define mass (table 1). The difference between the estimated injected mass $(2.26 \mathrm{~kg})$ and collected mass $(2.48 \mathrm{~kg}$ ) is probably due to error in streamflow estimates and (or) errors that may have been introduced in the calculation of the initial-injection quantity, in sampling, and in fluorescence measurement. 


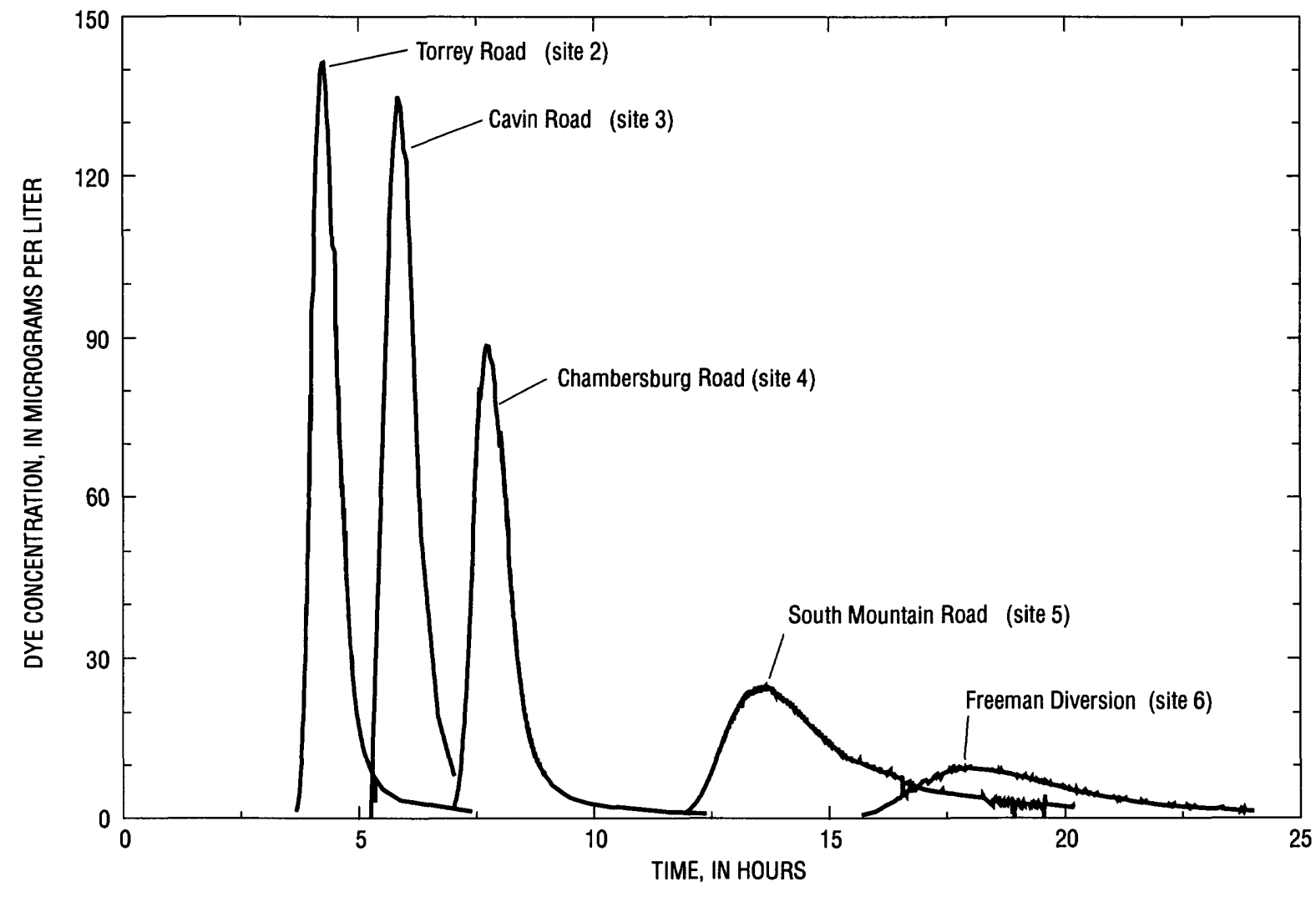

Figure 4. Relation between dye concentration and time at the five sampling sites on the Santa Clara River, Ventura County, California.

The peak concentration of dye traveled at an average velocity of $2.29 \mathrm{ft} / \mathrm{s}$. The measured flow velocities ranged from $1.84 \mathrm{ft} / \mathrm{s}$ at the Freeman Diversion (site 6) to $3.31 \mathrm{ft} / \mathrm{s}$ at Cavin Rd. (site 3). The traveltime of the peak concentration from Santa Felicia Dam to Freeman Diversion (site 6) was about 18 hours (table 1). Traveltime of the leading edge is approximately 84 percent of the traveltime of the peak concentration; this ratio is in agreement with the average ratio of 89 percent reported by Jobson (1996).

The total dye mass decreased continuously from the Piru site to Freeman Diversion (site 1 to site 6), while dye-cloud duration at a site increased, as indicated by increasing time variance (table 1 ). Time variance in dye-cloud duration is the mathematical expression of the increasing duration of dye-cloud passage.

From the Piru site to Torrey Road (site 1 to site 2 ), the decrease in dye mass was 33 percent, and flow loss was 7 percent (table 1). The mass loss is in excess of what can be explained by percolation to ground water. The upper subreach is perennial owing to releases from Santa Felicia Dam; the channel is relatively narrow, and the streambed is composed of fine to coarse materials. The loss of mass may have been caused by photodecay and (or) adsorption/desorption (Harvey Jobson, USGS, written commun., 1997).

From Torrey Road to Cavin Road (site 2 to site 3 ), the dye mass decreased by 12 percent, roughly in proportion to the loss of flow between these sites (that is, percolation of flow to ground water) (table 1). The manual samples at Cavin Road (site 3) did not fully capture the dye cloud, as shown by the truncated curve in figure 4. The small apparent dye-mass increase between Cavin Road and Chambersburg Road (sites 3 and 4) is not significant insofar as the estimated mass collected at Cavin road (site 3 ) is assumed to be inaccurate owing to the incomplete data collection at that site.

From Chambersburg Road to South Mountain Road (site 4 to site 5), net streamflow increased. On the basis of previous flow measurements, this increase can 
Table 1. Statistics from the time-concentration curves, Santa Clara River, October 1994 [mi, mile; $\mathrm{ft}^{3} / \mathrm{s}$, cubic foot per second; ft/s, foot per second; ft, foot; $\mu \mathrm{g} / \mathrm{L}$, microgram per liter; $\mathrm{kg}, \mathrm{kilogram}$; hr, hour; $\mathrm{hr}^{2}$, hour squared;--, no data]

\begin{tabular}{|c|c|c|c|c|c|c|c|c|c|c|c|c|c|}
\hline $\begin{array}{l}\text { Site } \\
\text { No. }\end{array}$ & $\begin{array}{c}\text { Site name } \\
\text { (abbrevia- } \\
\text { tion) }\end{array}$ & $\begin{array}{c}\text { Distance } \\
\text { from } \\
\text { injection } \\
\text { (mi) }\end{array}$ & $\begin{array}{c}\text { Dis- } \\
\text { charge } \\
\left(\mathrm{ft}^{3} / \mathrm{s}\right)\end{array}$ & $\begin{array}{c}\text { Average } \\
\text { velocity } \\
\text { in reach } \\
\text { (ft/s) }\end{array}$ & $\begin{array}{l}\text { Channel } \\
\text { width } \\
\text { (ft) }\end{array}$ & $\begin{array}{l}\text { Net flow } \\
\text { change } \\
\text { in reach } \\
\text { (percent) }\end{array}$ & $\begin{array}{c}\text { Peak } \\
\text { concen- } \\
\text { tration } \\
(\mu \mathrm{g} / \mathrm{L})\end{array}$ & $\begin{array}{c}\text { Dye } \\
\text { mass } \\
(\mathbf{k g})\end{array}$ & $\begin{array}{c}\text { Conser- } \\
\text { vative } \\
\text { peak } \\
(\mu g / L)\end{array}$ & $\begin{array}{c}\text { Dye } \\
\text { mass } \\
\text { change } \\
\text { in reach } \\
\text { (percent) }\end{array}$ & $\begin{array}{l}\text { Time } \\
\text { after } \\
\text { injection- } \\
\text { peak } \\
\text { (hr) }\end{array}$ & $\begin{array}{c}\text { Time } \\
\text { - varlance } \\
\left(\mathbf{h r}^{2}\right)\end{array}$ & $\begin{array}{l}\text { Coeffi- } \\
\text { cient } \\
\text { of } \\
\text { skew }\end{array}$ \\
\hline 1 & Piru & 0.10 & 167 & 2.89 & 49.5 & 0 & 3,810 & 12.26 & $3,810.0$ & 10 & 0.05 & (2) & (2) _ \\
\hline 2 & Torrey Road & 6.55 & 155 & 2.26 & 60.0 & -7 & 141 & 1.67 & 191.4 & -33 & 4.25 & .23 & 80.3 \\
\hline 3 & Cavin Road & 10.11 & 142 & 3.31 & 51.5 & -8 & 135 & ${ }^{3} 1.47$ & 207.0 & -12 & 5.83 & (2) & (2) _ \\
\hline 5 & S. Mtn Br. & 22.62 & 163 & 2.03 & 64.0 & 13 & 25 & 1.35 & 42.0 & -11 & 13.68 & 3.14 & 37.6 \\
\hline 6 & $\begin{array}{l}\text { Freeman } \\
\text { Diversion }\end{array}$ & 28.04 & 152 & 1.84 & - & -7 & 10 & .64 & 34.2 & -47 & 17.99 & 3.74 & 12.8 \\
\hline
\end{tabular}

${ }^{1}$ Mass injected into Piru Creek.

${ }^{2}$ Time variance and the coefficient of skew cannot be calculated for these sites because of the lack of a complete collection of dye passing these sites.

${ }^{3}$ Approximate total from manual sampling; does not include the tail of the dye plume.

be attributed to the combined effects of recharge in the upper part of the Fillmore Subbasin and ground-water discharge at the Fillmore Narrows just upstream from South Mountain Road (site 5) (table 1). Flow measurements made 1 month earlier indicated a 7.5 percent flow loss (equivalent to $12 \mathrm{ft}^{3} / \mathrm{s}$ during the dye test) in the upper part of the Fillmore Subbasin. Approximately $8 \mathrm{ft}^{3} / \mathrm{s}$ of flow was diverted just upstream from South Mountain Road (site 5) during the test. Estimated flow loss in this subreach is therefore 13 percent $\left[\left(12 \mathrm{ft}^{3} / \mathrm{s}\right.\right.$ $\left.+8 \mathrm{ft}^{3} / \mathrm{s}\right) / 158 \mathrm{ft}^{3} / \mathrm{s}$ ]. Dye mass decreased 11 percent, roughly in proportion to the magnitude of estimated flow loss.

From South Mountain Road to Freeman Diversion (site 5 to site 6$)$, streamflow decreased slightly ( 7 percent), but dye mass decreased dramatically (47 percent) (table 1). At Freeman Diversion (site 6), sampling stopped before concentrations reached pre-test levels. Freeman Diversion creates a ponding effect, and there is much vegetation and algae in and around this subreach of the channel. Adsorption of dye onto organic material or fine sediment may account for the mass losses in excess of percolation to ground water. The excess loss cannot be explained by photodecay of the dye because no similar losses occurred during the peak sunlight hours [for example, from Torrey Road (site 2) to Chambersburg Road (site 4)]. Additionally, the dye passed between South Mountain Road and Freeman Diversion (sites 5 and 6) during hours of darkness.

\section{Statistical Analysis of Tracer-Test Results}

Nordin and Sabol (1974) developed statistical tests to determine if a river follows Fick's Law of diffusion, which states that for a Fickian river, the mass flux per unit area per unit time is proportional to the concentration gradient. The convection-dispersion equation (Nordin and Sabol, 1974) is:

$$
\frac{\partial C}{\partial t}=D_{x} \frac{\partial^{2} C}{\partial x^{2}}-\bar{U} \frac{\partial C}{\partial x},
$$

where

$C$ is the cross-sectional average concentration,

$\bar{U}$ is the mean velocity, and

$D_{\mathrm{x}}$ is a constant longitudinal-dispersion coefficient.

Equation 2 assumes that dispersion is linearly related to the gradient of concentration, and does not address the loss of mass owing to first-order decay or other processes.

The effects of dye loss from the plume are first accounted for using the unit peak concentration $\left(C_{u}\right)$, which is calculated (Jobson, 1996) with the equation:

$$
C_{u}=1 \times 10^{6} \times \frac{C}{M_{r}} \times Q,
$$

where

$C$ is the tracer concentration,

$M_{r}$ is the mass of tracer to pass a cross section, and

$Q$ is the stream discharge. 


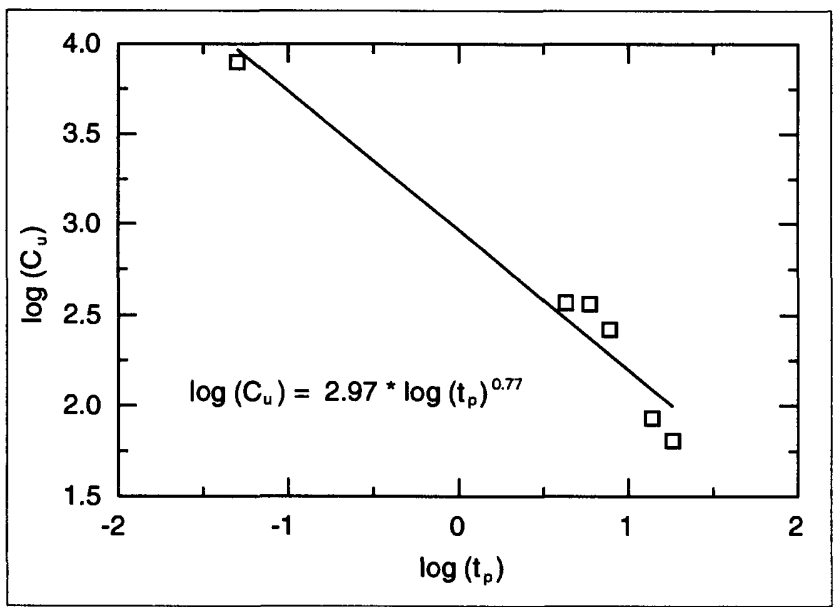

Figure 5. Relation of unit-peak dye concentration $\left(C_{u}\right)$ to peak traveltime $\left(t_{p}\right)$. Line and equation were computed by linear regression on log-transformed variables, transformed by taking the base -10 logarithm.

If a river is Fickian, the unit peak concentration $\mathrm{C} \mathrm{Cu}$ ) should attenuate with the square root of time (eq. 4), variance of the distributions should increase linearly with time (eq. 5), and the distance the centroid has moved downstream should increase linearly with time (eq. 6) (Jobson, 1996; Nordin and Sabol, 1974).

$$
\begin{gathered}
C_{u}=d t_{p}^{-B}, \\
\sigma_{t}^{2}=c t^{2 H}, \\
x=a t^{b},
\end{gathered}
$$

where

$C_{u}$ is unit peak concentration $\left(\mu \mathrm{L}^{-3}\right)$,

$t_{p}$ is time to peak concentration ( $\left.\mathrm{t}\right)$,

$\sigma_{t}^{2}$ is time variance of concentration distribution $\left(\mathrm{t}^{2}\right)$

$t$ is time to centroid $(\mathrm{t})$,

$x$ is distance to centroid (l), and

$a, b, c, d, H, B$ are regression coefficients, and $b=1.0, H=0.5$, and $B=0.5$.

In addition, the concentration distribution of a conservative tracer, at an instant in time, should be

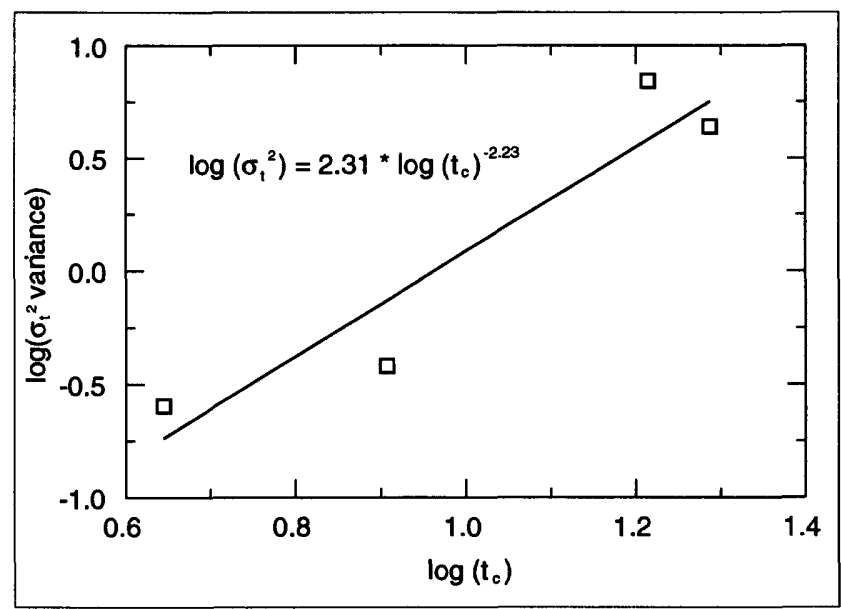

Figure 6. Relation of dye-cloud variance $\left(\sigma_{t}{ }^{2}\right)$ to time to the centroid $\left(t_{c}\right)$. Line and equation were computed by linear regression on log-transformed variables, transformed by taking the base -10 logarithm.

symmetric (Nordin and Sabol, 1974). Of the 51 rivers they studied, Nordin and Sabol (1974) found that only 6 rivers were Fickian.

Linear regression was used to analyze the relation of unit peak concentration, $C_{u}$, and peak traveltime, $t_{p}$, after the data were log-transformed (eq. 4; fig. 5). The Santa Clara River differs from the streams studied by Nordin and Sabol (1974) in that its perennial flow is maintained by releases from Santa Felicia Dam, yet the estimated regression coefficient $B, 0.77$ indicates a rate of decrease in unit peak concentration over time that is very nearly Fickian, as predicted by theory (Jobson, 1996; Nordin and Sabol, 1974).

Linear regression was used to analyze the relation between variance and traveltime of the centroid after the data were log-transformed (eq. 5; fig. 6). The estimated slope (the exponent $2 H$ in eq. 5), 2.31, is higher than Fickian theory predicts, and it is among the highest exponents given by Nordin and Sabol (1974) in the summary of dispersion data.

Linear regression was used to analyze the relation between the distance the centroid has moved downstream and time to the centroid after the data were log-transformed (eq. 6; fig. 7). As the log of time to the centroid increased, the log distance to the centroid increased; the slope is close to one (fig. 7), as is observed in the ideal Fickian process of longitudinal dispersion (Nordin and Sabol, 1974).

The Santa Clara River tracer data show the river to be nearly Fickian. The rate of $C_{u}$ decreased with increasing time (eq. 4), and the distance that the cen- 


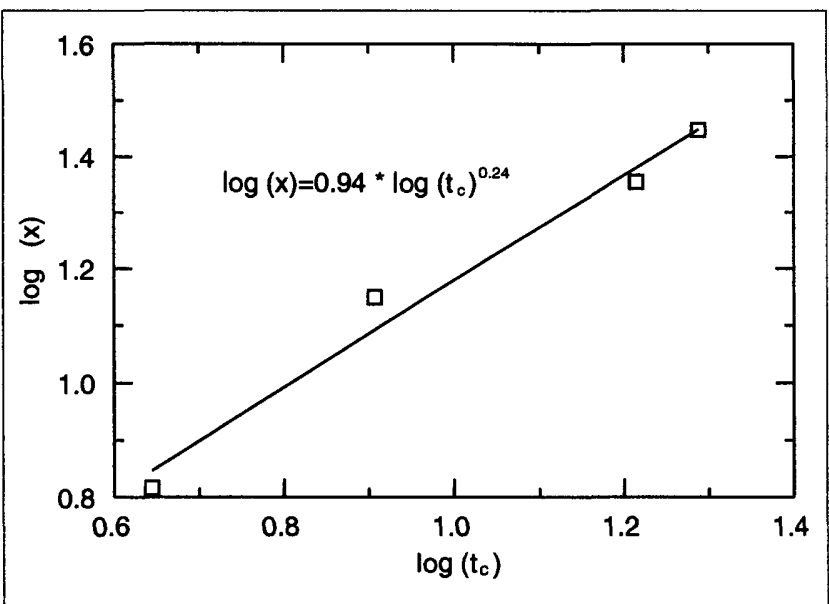

Figure 7. Relation of distance to centroid $(x)$ to time to centroid $\left(t_{c}\right)$. Line and equation were computed by linear regression on log-transformed variables, transformed by taking the base -10 logarithm.

troid moved downstream increased linearly with time (eq. 6); these results are consistent with Fickian theory. Time variance was higher than the theory predicts (eq. 5 ), and the asymmetry of the time-concentration curves, as shown by the long tails and skewness (table 1), is not predicted by the theory (Nordin and Sabol, 1974). Long tails and skewness are characteristic of natural streams.

\section{NUMERICAL MODELS USED TO EVALUATE THE TRACER-TEST RESULTS}

To better understand the dye transport in the tracer test, two one-dimensional numerical models were applied to data from this study: a flow model, DAFLOW (Jobson, 1989), and a solute-transport model, BLTM (Jobson and Schoellhamer, 1993).

DAFLOW solves the continuity and diffusion-wave equations using a diffusion analogy. BLTM uses the flow information provided by DAFLOW and solves the advection-dispersion equation, including first-order decay, in a Lagrangian coordinate system. These simplified one-dimensional surface-water flow and solutetransport models were used because the insufficiency of hydraulic data (for example, detailed channel geometry and bed slope) precluded the application of sophisticated streamflow and transport models.

\section{Flow Model (DAFLOW)}

Specifically, DAFLOW considers the onedimensional continuity equation:

$$
\frac{\partial Q}{\partial x}+\frac{\partial A}{\partial t}=0
$$

and the diffusion wave equation:

$$
\frac{\partial Y}{\partial x}+S_{f}-S_{o}=0
$$

where $Q$ is volumetric flow rate,

$A$ is area of flow,

$x$ is longitudinal distance along the channel,

$t$ is time,

$Y$ is depth of flow,

$S_{\mathrm{f}}$ is friction slope, and

$S_{\mathrm{o}}$ is bed slope (Jobson, 1989).

The diffusion-wave equation is solved using the diffusion analogy method and additional simplifying assumptions.

Jobson (1989) assumes that cross-sectional area can be related to the flow rate by:

$$
A=A 1 Q S^{A 2}+A 0,
$$

where $A 1$ and $A 2$ are hydraulic geometry coefficient and hydraulic geometry exponents, respectively, for area,

$Q S$ is discharge normal to the cross-sectional area, and

$A 0$ is average cross-sectional area at zero flow. $A 0$ accounts for water stored in the pools of a river reach that would not completely drain if flow were stopped (Jobson, 1989). Similarly, the width, $W$, is assumed to have the following relation with flow rate:

$$
W=W 1 Q S^{W 2}
$$


where $W 1$ and $W 2$ are hydraulic geometry coefficient and exponent, respectively, for width. Jobson (1989) gives a table of reported hydraulic geometry exponents. Leopold and Maddock (1953) stated that $A 2$ should be less than or equal to 1.0 .

Applying the hydraulic relations to the diffusionwave equation yields:

$$
\frac{\partial}{\partial t}(Q S)+C \frac{\partial}{\partial \chi}(Q S)-D F \frac{\partial^{2}}{\partial \chi^{2}}(Q S)=0
$$

where $C$ is constant wave speed, and $D F$ is the wavedispersion coefficient. In this form, the mass of water per unit length of stream channel obeys the onedimensional, advection-dispersion equation, which is relatively easy to solve using a three-step finitedifference approach.

Additional information regarding DAFLOW is given by Jobson (1989).

\section{Solute-Transport Model (BLTM)}

BLTM solves the one-dimensional solutetransport equation with first-order decay in a Lagrangian reference frame. The governing equation is:

$$
\frac{\partial c}{\partial t}-\frac{\partial}{\partial \zeta}\left(D \frac{\partial c}{\partial \zeta}\right)=s-k\left(c-c_{R}\right)
$$

where $\zeta$ is the Lagrangian distance coordinate given by:

$$
\zeta=x-x_{o}-\int_{t_{o}}^{t} u d t
$$

and where $t=$ time,

$x$ is distance along river,

$x_{0}$ is initial location of the Lagrangian fluid parcel,

$u$ is $\left(x / t_{p}\right)$

$c$ is concentration of solute,

$D$ is dispersion coefficient, $s$ is source term,

$k$ is first-order decay coefficient, and $c_{R}$ is concentration of solute at which decay or
desorption is zero.

The governing equation is solved using an explicit finite-difference approximation. The flow information is supplied to BLTM by DAFLOW. Note that BLTM addresses dispersion using a dimensionless dispersion factor $\left(D_{f}\right)$ where:

$$
D_{f}=D /\left(u^{2} \cdot d t\right)
$$

Additional information regarding BLTM is given by Jobson and Schoellhamer (1993).

\section{MODEL APPLICATION TO TRACER-TEST RESULTS}

\section{Model Design}

The basic model design is the same for DAFLOW and BLTM (see Jobson, 1989; and Jobson and Schollhamer, 1993). A schematic of the models is shown in figure 8 . The Santa Clara River system is divided into three branches; a branch is defined as a one-dimensional river segment. Branch 1 represents the Santa Clara River from the Los Angeles-Ventura County line to the intersection with Piru Creek, Branch 2 represents Piru Creek from Santa Felicia Dam to the Santa Clara River, and Branch 3 represents the Santa Clara River from Piru Creek downstream to the Freeman Diversion (fig. 8). Each branch starts and ends in a junction; there are four junctions in this model. Each branch also contains grid points where the hydraulic geometry parameters, tributaries (inflow and outflow), solute source and sink data are specified; transport parameters also are specified. Note that DAFLOW does not allow for tributary flow at the junctions. There must be a grid point at each end of a branch and each branch can contain additional grid points. The grid points do not have to be evenly spaced nor is there a restriction on the distance between grid points. Branch 1 contains two grid points, branch 2 contains three grid points, and branch 3 contains nine grid points. In general, the grid points correspond to locations where flow and geometry data are available. The distances between grid points are given in figure 8 . 


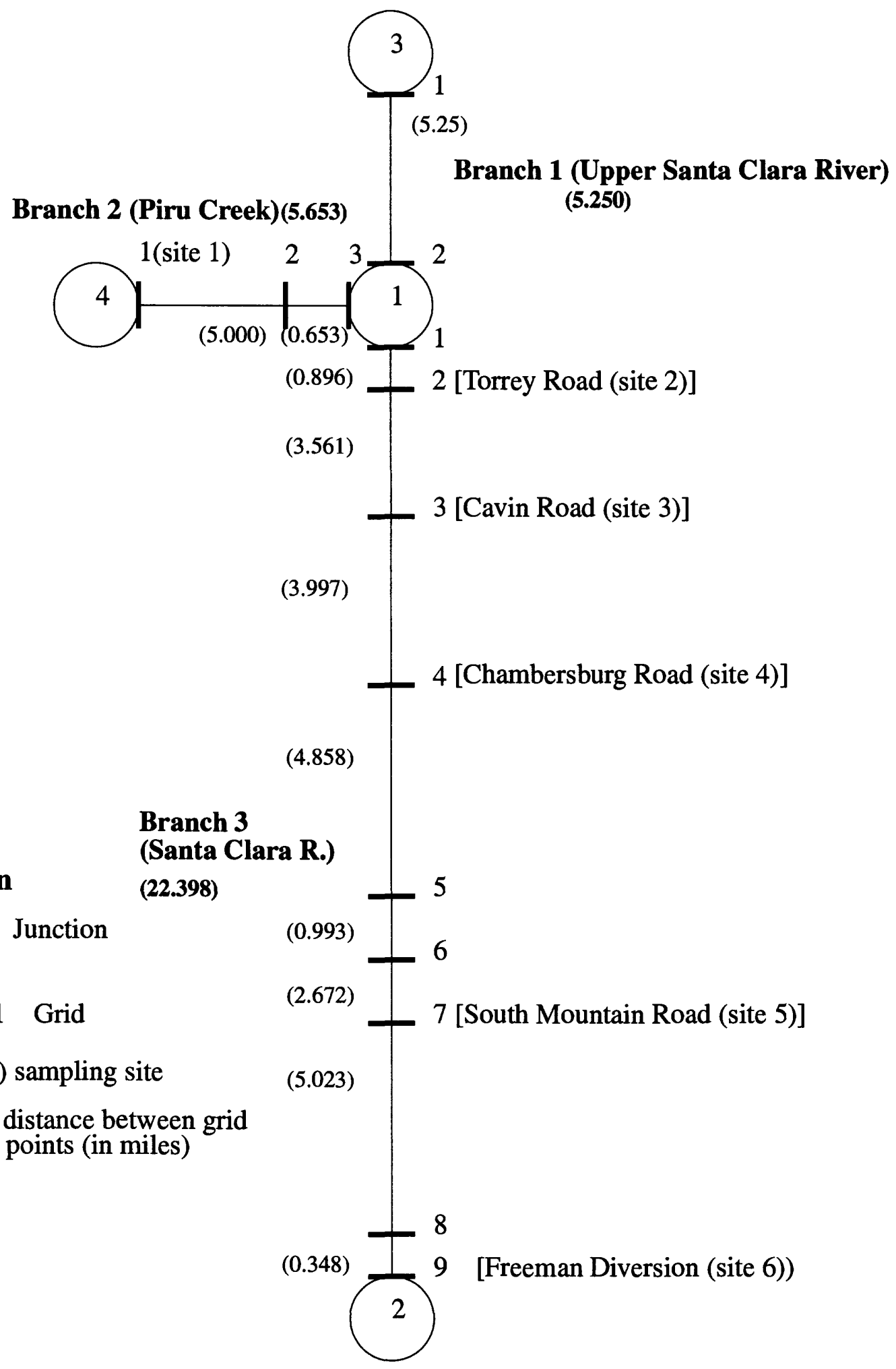

Figure 8. Division of the study area into branches and grid points for application of the flow and solute-transport models, Ventura County, California. 
Table 2. Flow rates and tributary flow rates used in DAFLOW

[Branch 2, grid 3, and branch 3, grid 8, are added for modeling purposes in order to represent gains and losses near model junctions and do not have observed flow rates. Flow rates at branch 2, grid 2, and branch 3, grids 5 and 6, are estimates based on measurements made in September 1994. Flow rates at all other sites were measured during the dye test. Tributary flow rate: Actual tributary inflows were zero; the values shown for tributary flow rate actually are estimates of losses to $(-)$ and gains from $(+)$ the subsurface]

\begin{tabular}{lccccccccc}
\hline & \multicolumn{2}{c}{ Branch 2 } & \multicolumn{6}{c}{ Branch 3 } \\
\hline & $\begin{array}{c}\text { Grid 1 } \\
\text { (site 1) }\end{array}$ & Grid 2 & $\begin{array}{c}\text { Grid 2 } \\
\text { (site 2) }\end{array}$ & $\begin{array}{c}\text { Grid 3 } \\
\text { (site 3) }\end{array}$ & $\begin{array}{c}\text { Grid 4 } \\
\text { (site 4) }\end{array}$ & Grid 5 & Grid 6 & $\begin{array}{c}\text { Grid 7 } \\
\text { (slte 5) }\end{array}$ & $\begin{array}{c}\text { Grid 8 } \\
\text { (site 6) }\end{array}$ \\
\hline $\begin{array}{l}\text { Observed } \\
\text { flow rate } \\
\left(\mathrm{ft}^{3} / \mathrm{s}\right)\end{array}$ & 167 & 159 & 155 & 142 & 158 & 146 & 158 & 163 & 152 \\
$\begin{array}{c}\text { Tributary } \\
\text { flow rate } \\
\left(\mathrm{ft}^{3} / \mathrm{s}\right)\end{array}$ & $\begin{array}{c}\text { Boundary } \\
\text { condition }\end{array}$ & -4 & -12 & -13 & 16 & -12 & 12 & -8 & -11 \\
\hline
\end{tabular}

\section{DAFLOW Model}

As stated earlier, tributary information is specified at the grid points, and hydraulic geometry coefficients apply to subreaches. Subreach 1 , for example, extends from grid 1 to grid 2 . The flow parameters are discussed in detail in the next section. Recall that steady flow within the study subreaches was attained through controlled releases of water from Santa Felicia Dam. The tributary inflows and outflows are those flow rates needed to match the steady-state flow rates observed at the grid points. In this model, the tributaries are used to represent ground-water recharge and discharge; the actual tributary flows were approximately zero, with the exception of an $8-\mathrm{ft}^{3} / \mathrm{s}$ diversion upstream from South Mountain Road (site 5). The steady-state flow rates and related tributary flows are given in table 2 .

\section{BLTM Model}

As stated earlier, the solute source and sink data are specified at the grid points, and transport parameters are specified for each subreach. Note that the simulated concentration at a given node is affected by the upstream decay coefficients. The transport parameters are discussed in detail in the next section. The input of dye was modeled as a time-varying input taking place over 30 minutes (from 6 minutes after the start of the experiment to 36 minutes after) at branch 2 , grid point 1 , on the basis of data collected at site 1 , just downstream from the Santa Felicia Dam. No other sources or sinks were specified although solute mass may leave the river systems at grid points with outflow tributaries (that is, ground-water recharge or diversions).

\section{Parameter Starting Estimates for DAFLOW and BLTM}

A total of seven parameters must be estimated for use in DAFLOW and BLTM [five flow parameters ( $A 0, A 1, A 2, W 1$, and $W 2$ ) for DAFLOW (see eqs. 9-10) and two transport parameters $(k$ and $D$ ) for BLTM (see eqs. 12-14)]. The initial values of the flow parameters were estimated using the streamflow data collected during 1993-95 by the USGS on Piru Creek and the Santa Clara River (Reichard and others, USGS, written commun., 1997). These data included flow rate, crosssectional area, and width. There are four subreaches in the models: Piru Creek in the Piru Subbasin and the Santa Clara River in the Piru, Fillmore, and Santa Paula Subbasins (see fig. 1). Linear regression analyses were performed to estimate the flow parameters for each subreach; the equations had the following form:

$$
\ln A=\ln A 1+A 2 \cdot \ln Q
$$

and

$$
\ln W=\ln W 1+W 2 \cdot \ln Q
$$

Note that these equations are log transformations of equations 9 and 10 , with $A O$ assumed to equal zero in equation 15 . The results for the linear regression on the data for the six sites in this study are shown in figures 9-12, and the initial parameters computed from these regressions are given in table 3 . The coefficients are based on point values, and the true values should be based on a spatial average of $A$ and $W$. That is, within a subreach, $A$ equals the volume of water divided by the 


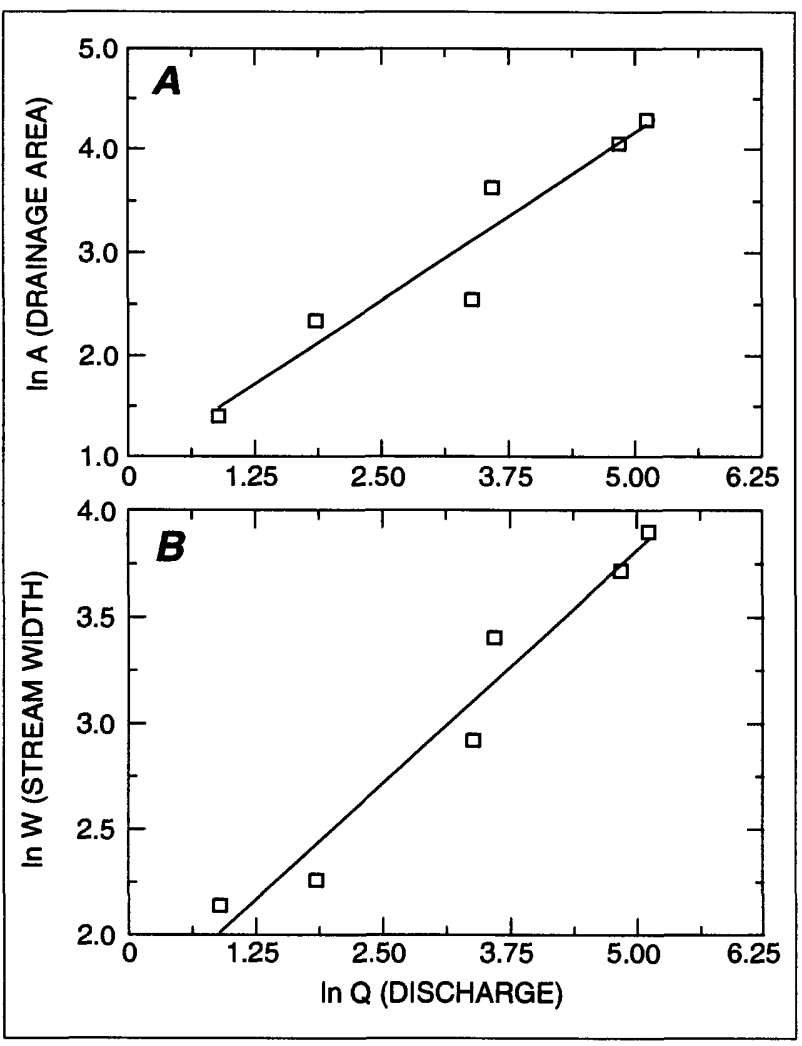

Figure 9. Relation of drainage area to discharge (A), and relation of stream width to discharge (B) for Piru Creek, Ventura County, California. Lines were computed by linear regression on natural logarithims of the values.

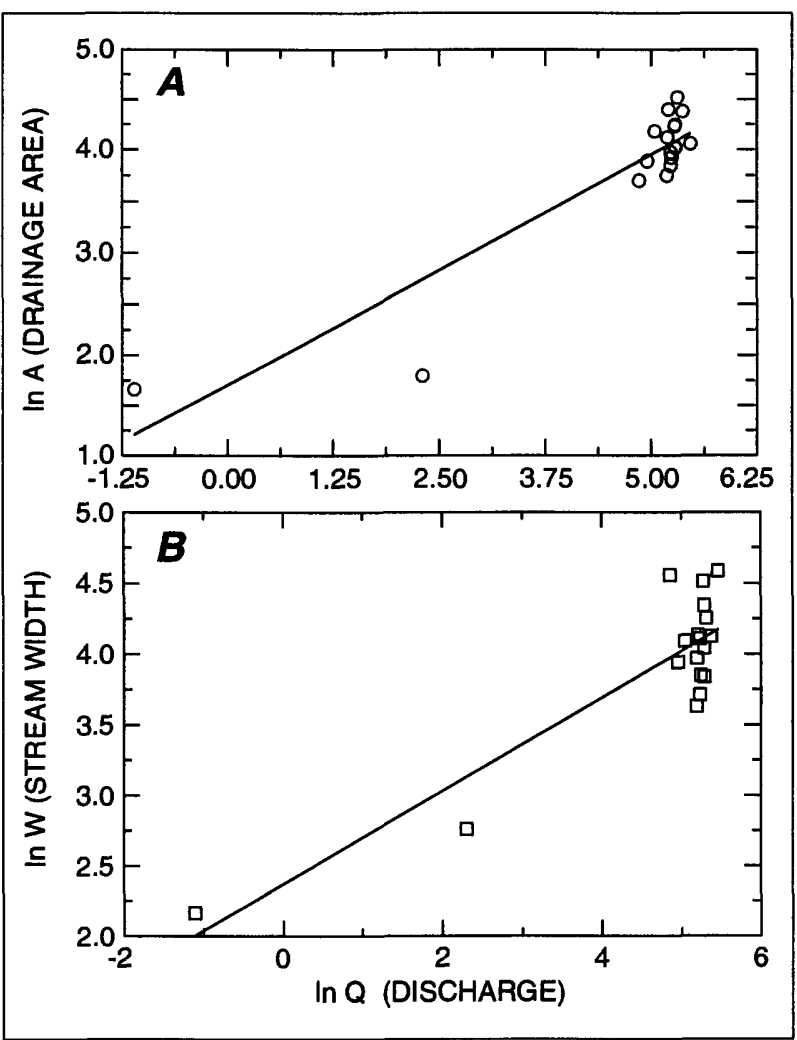

Figure 10. Relation of drainage area to discharge (A), and relation of stream width to discharge (B) for Piru Subbasin, Ventura County, California. Lines were computed by linear regression on natural logarithims of the values.

Table 3. Initial hydraulic geometry parameters for the flow model (DAFLOW)

[Values were determined by linear regression using data from all discharge measurements in each reach. $A 0$ was initially assumed to be zero]

\begin{tabular}{lllrrr}
\hline \multicolumn{1}{c}{ Branch } & & Subbasin & A1 & A2 & W1 \\
\hline 2 (Piru Creek) & Piru & 2.474 & 0.652 & 5.048 & 0.439 \\
3 (Santa Clara River) & Piru & 5.512 & .449 & 10.697 & .331 \\
& Fillmore & 2.212 & .657 & 4.716 & .525 \\
& Santa Paula & 1.298 & .811 & 5.191 & .547 \\
\hline
\end{tabular}

length of the subreach, and $W$ equals the surface area of water divided by the length of the subreach. The flowparameter estimates are greater than those reported in the literature (see Jobson, 1989; Leopold and Maddock, 1953).

The flow-parameter estimates were refined and the transport parameters were estimated using a modified form of the parameter-estimation method outlined by Jobson (1987). First, the modeled time to arrival for the peak concentration was matched to the observed data by manipulating the cross-sectional area coefficients, including $A 0$. The mean error between the simulated and observed data was forced to be as close to zero as possible by varying the decay coefficient, $k$. The root-mean-squared error was then minimized by varying the dispersion factor, $D_{f}$. This was performed on a trial and error basis, in an iterative process, one subreach at a time. The final parameter estimates are given in table 4, and the resulting model simulations are shown in figure 13. It should be noted that the underlying goal during the parameter-estimation process was to best match the peak-concentration values as opposed to attempting to best match the total mass; the implications of this approach are discussed below. 


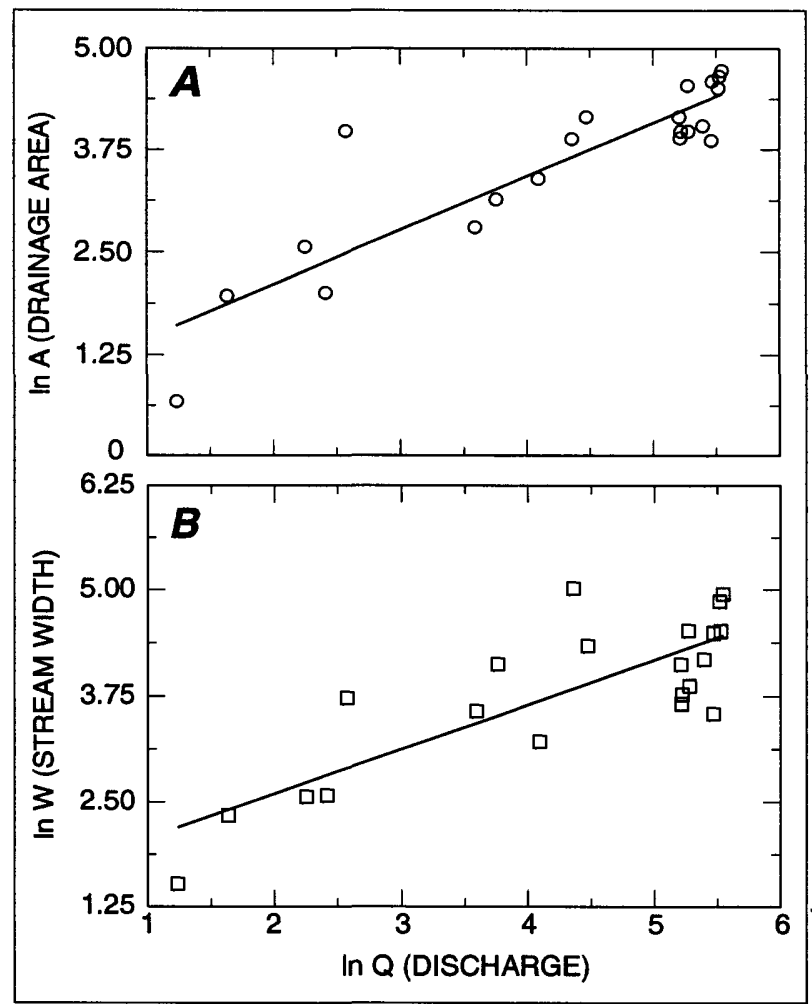

Figure 11. Relation of drainage area to discharge (A), and relation of stream width to discharge (B) for Fillmore Subbasin, Ventura County, California. Lines were computed by linear regression on natural logarithims of the values.

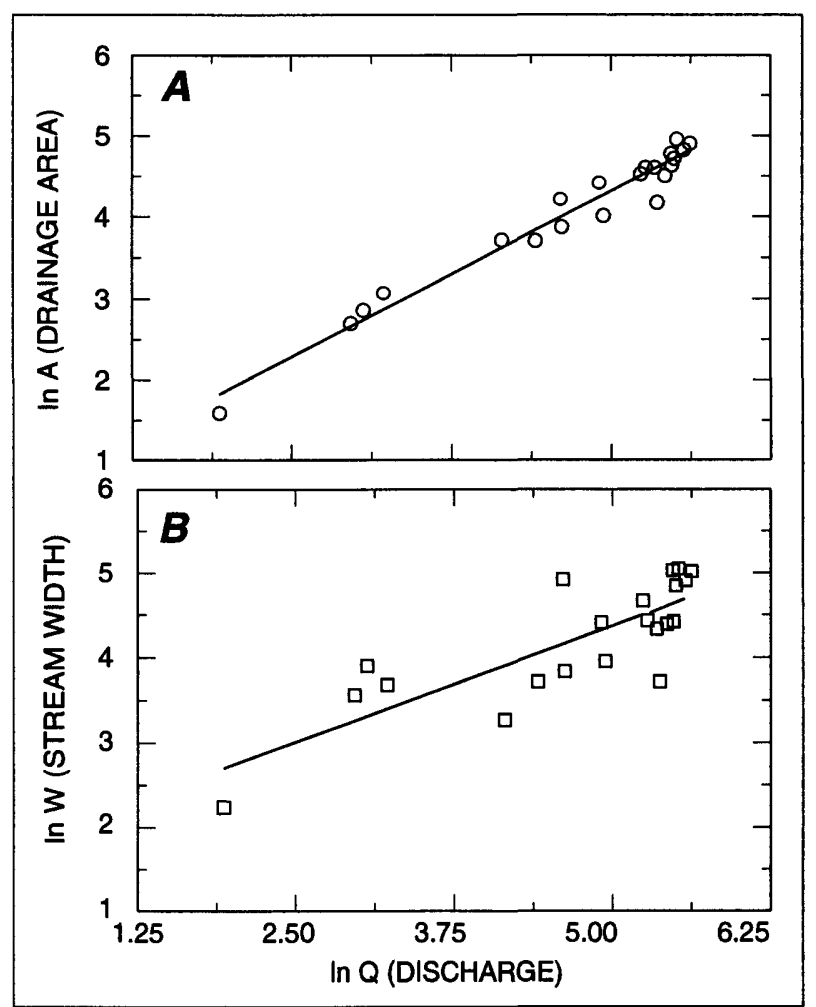

Figure 12. Relation of drainage area to discharge (A), and relation of stream width to discharge (B) for Santa Paula Subbasin, Ventura County, California. Lines were computed by linear regression on natural logarithims of the values.

Table 4. Final parameter estimates for DAFLOW and BLTM, Ventura County, California $\left[\mathrm{ft}^{3} / \mathrm{s}\right.$, cubic foot per second; -, no data]

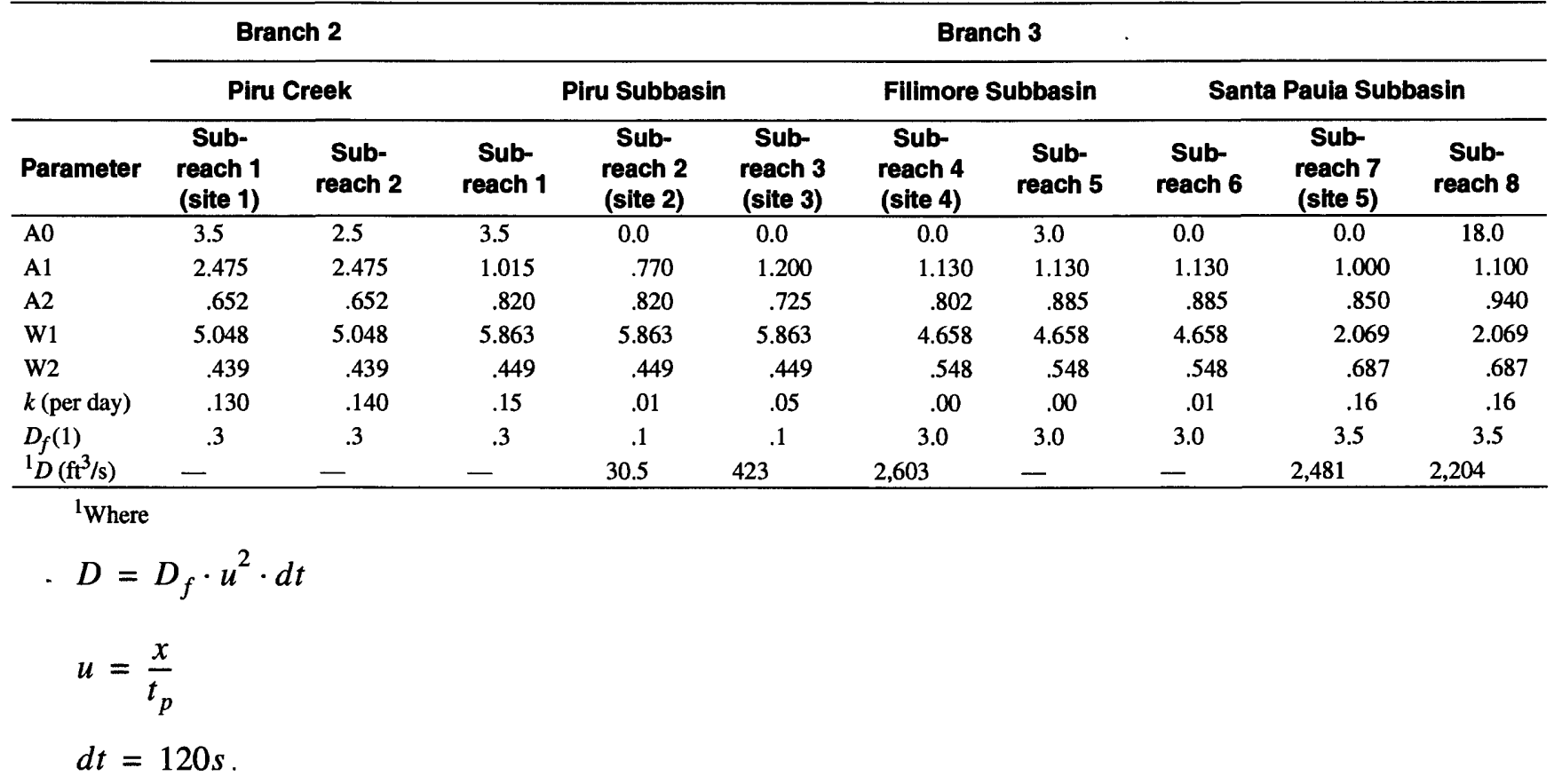




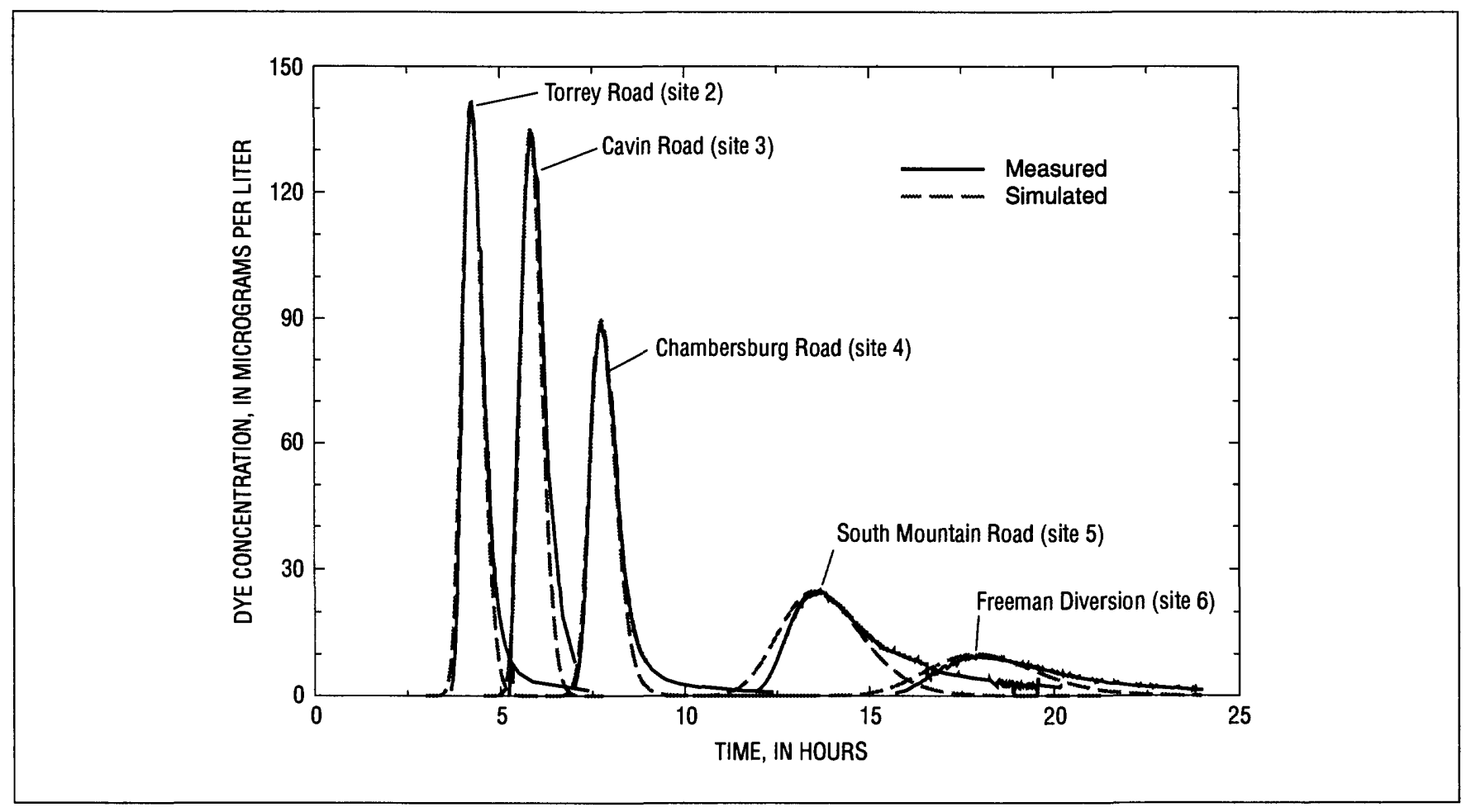

Figure 13. Measured and model-simulated dye concentration at sites 2-6 on the Santa Clara River during the 24-hour test, Ventura County, California.

\section{MODEL RESULTS}

The final measured values and model-simulated test results for the Torrey Road (site 2), Cavin Road (site 3), Chambersburg Road (site 4), South Mountain Road (site 5), and Freeman Diversion (site 6) sites are presented in figure 13. In addition, the simulated and measured mass, time to peak, and peak-concentration data given are in table 5.

The relatively large first-order decay coefficient ( $k$ ) values (about $0.14 /$ day) computed for the reach from the insertion point below Piru Creek (site 1) to Torrey Road (site 2) reflects the loss of solute mass between the two sites (table 5). The loss of mass not explained by flow loss may be caused by photodecay or adsorption/desorption. The decay coefficient is a lumped parameter and the effects of these processes cannot be separated. The dispersion factor $\left(D_{f}\right)$ and dipersion coefficient $(D)$ are very small (table 4$)$, as indicated by the sharp shape of the measured and simulated breakthrough curve (fig.13). This was also the only reach besides the pool upstream from the Freeman Diversion (site 6) for which the coefficient $A 0$ is greater than zero (table 4 ). The parameter $A 0$ is increased during model calibration to slow the computed concentration peak; the increase is meant to account for temporary storage of dye in zones of low velocity, or slow mixing with the main mass of the flow (dead zones).

The $k$ value used between Torrey Road (site 2) and Chambersburg Road (site 4) (about 0.03/day) is much smaller than the values upstream from Torrey Road (site 2) (table 4), indicating that little dye loss is simulated by first-order decay in the subreach between Torrey Road and Chambersburg Road (sites 2 and 4) (table 5). A similar pattern occurred between Torrey Road and Cavin Road (site 3, grid 3) (table 5). The loss of mass $(0.15 \mathrm{~kg}$ and $0.20 \mathrm{~kg}$ [simulated and measured, respectively] or about $10 \%$ ) at Torrey Road can be explained by the loss of streamflow to ground-water recharge (modeled as a tributary outflow). The $D_{f}$ and $D$ values at site 4 are much larger than values at the upstream sites (figure 13 and table 4), as indicated by the greater spread of the breakthrough curve at site 4 in comparison with the upstream sites.

The $k$ value (about 0.0 /day) indicates that no loss of mass is simulated for first-order decay between Chambersburg Road (site 4) and South Mountain Road 
Table 5. Measured and model-simulated mass, time-to-peak, and peak-concentration values for sites $2-6$ on the Santa Clara River

[kg, kilogram; hr, hour; $\mu \mathrm{g} / \mathrm{L}$, microgram per liter]

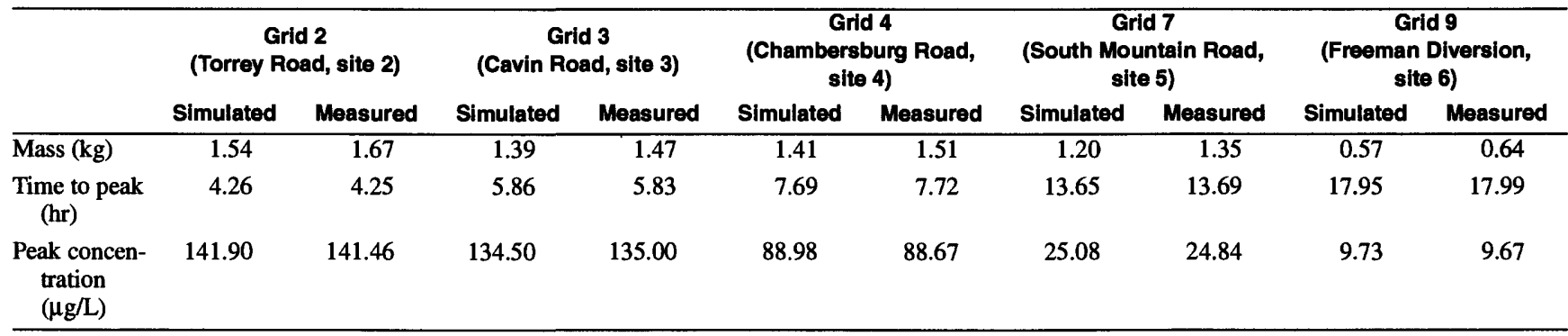

(site 5). The measured and simulated loss of mass between Chambersburg Road and South Mountain Road (sites 4 and 5) can be explained by the loss of streamflow to ground-water recharge in the upper part of this subreach, and by the diversion just upstream from South Mountain Road (site 5). In this case, the $D_{f}$ value is relatively large (table 4), as indicated by the greater spread of the breakthrough curve. Note that the fit of the leading edge could be improved by decreasing $D f$, but this would increase the root-mean-squared error.

The $k$ value (about $0.16 /$ day) for Freeman Diversion (site 6) is approximately equal to that computed for the reach upstream from Torrey Road (site 2). Freeman Diversion causes a ponding of water, thereby reducing the velocity of the flow. This lake-like effect, coupled with any organic material in this area, could cause a loss of mass through adsorption, and this requires a large $k$ value. The breakthrough curve is dispersed, yielding a large $D f$ value. Again, an improved fit of the leading edge could be made by decreasing the $D f$ value, thereby resulting in an increased root-mean-squared error.

\section{CONCLUSIONS}

A 24-hour dye-tracer test was completed on a 28mile reach of the Santa Clara River to better understand flow and transport processes and ground-water/ surface-water interactions. The Santa Clara River is unique among those studied in most dye tests in that the flow is not naturally perennial in most subreaches.

Traveltime and flow velocities, peak concentration, and longitudinal dispersion data were obtained using the tracer method. The data indicate that the uppermost and lowermost subreaches lost more dye mass than can be explained by infiltration to the river bed. These losses may be caused by a combination of photodecay and (or) adsorption/desorption.

The exponent obtained from the nonlinear regression of peak concentration and traveltime is the same as that expected in a natural stream, and is similar to results obtained in previous dye studies. These data indicate that flow in the Santa Clara River fits Fickian theory.

The streamflow tracer study was successfully modeled using a combination of simple, onedimensional flow (DAFLOW) and solute-transport (BLTM) models. The values of hydraulic parameter geometry determined by model calibration are larger than those reported in the literature; however, a river of this type was not addressed in the literature. The nonzero $\mathrm{A} 0$ value used in the uppermost and lowermost subreaches was required to reduce the simulated velocities for an improved match between the measured and simulated time to peak concentration, indicating that these subreaches have pools that are not completely drained when flow is stopped.

The tails of the observed breakthrough curves are not successfully simulated. The poor fit of the tails may be caused by transient storage in pools or bank storage; these are transport phenomena that BLTM cannot address.

Large values of the linear decay coefficient $(k)$ are required in the uppermost and lowermost subreaches of the model to simulate for the loss of solute mass in these reaches. These $k$ values cannot account for any losses resulting from effects such as photodecay or adsorption/desorption. The greatest loss of mass takes place in the uppermost subreach between Santa Felicia Dam and Torrey Road. The BLTM model 
could not simulate this loss using only first-order decay, and this difference between the measured and simulated masses was carried on downstream to the Freeman Diversion.

In this study, the models predicted correctly the time to peak concentration, but underpredicted the total mass. Nonetheless, the combination of DAFLOW and BLTM can be used to predict the transport of a conservative pollutant, and can aid in management decisions that relate to other water-quality and recharge issues in the Santa Clara River.

\section{REFERENCES CITED}

Broshears, R.E., Bencala, K.E., Kimball, B.A., and McKnight, D.M., 1993, Tracer-dilution experiments and solute-transport simulations for a mountain stream, Saint Kevin Gulch, Colorado: U.S. Geological Survey Water-Resources Investigations Report 92-4081, $18 \mathrm{p}$.

Densmore, J.N., Middleton, G.K., and Izbicki, J.A., 1992, Surface-water releases for ground-water recharge, Santa Clara River, Ventura County, California, in Herrmann, Raymond, ed., Managing water resources during global change, American Water Resources Association, 28th Annual Conference and Symposium, Reno, Nevada, November 1-5, Proceedings, p. 407416.

Edwards, T.K., and Glysson, G.D., 1988, Field methods for measurement of fluvial sediment: u.S. Geological Survey Open File Report 86-531, 118 p.

Graf, J.B., 1995, Measured and predicted velocity and longitudinal dispersion at steady and unsteady flow, Colorado River, Glen Canyon Dam to Lake Mead: Water Resources Bulletin, v. 2, no. 31, p. 265-281.

Guy, H.P., and Norman, V.W., 1970, Field methods for measurement of fluvial sediment: U.S. Geological Survey Techniques of Water-Resources Investigations, book 3, chap. C2, 59 p.

Harvey, J.W., Wagner, B.J., and Bencala, K.E., 1996, Evaluating the reliability of the stream tracer approach to characterize stream-subsurface water exchange: Water Resources Research, v. 32, no. 8, p. 2441-2451.
Ishii, A.L., and Wilder, J.E., 1993, Effect of boundarycondition data selection on unsteady-flow model calibration, in Proceedings of the 25th Congress of International Association for Hydraulic Research, Vol. 1, August 30-September 3, 1993: Tokyo, Japan, p. 193200.

Jobson, H.E., 1987, Estimation of dispersion and first-order rate coefficients by numerical routing: Water Resources Research, v. 1, no. 23, p. 169-180.

Jobson, H.E., 1989, Users manual for an open-channel streamflow model based on the diffusion analogy: U.S. Geological Survey Water-Resources Investigations Report 89-4133, 73 p. 1996, Prediction of traveltime and longitudinal dispersion in rivers and streams:U.S. Geological Survey Water-Resources Investigations Report 96-4013, 69 p.

Jobson, H.E., and Schoellhamer, D.H., 1993, Users manual for a branched Lagrangian transport model: U.S. Geological Survey Water-Resources Investigations Report 87-4163, 80 p.

Kilpatrick, F.A., and Cobb, E.D., 1985, Measurement of discharge using tracers: U.S. Geological Survey Techniques of Water-Resources Investigations, book 3, chap. A16, 52 p.

Kilpatrick, F.A., and Wilson, J.F., Jr., 1989, Measurement of time of travel in streams by dye tracing: U.S. Geological Survey Techniques of Water-Resources Investigations, book 3, chap. A9, 27 p.

Leopold, L.B., and Maddock, Thomas, Jr., 1953, The hydraulic geometry of stream channels and some physiographic implications: U.S. Geological Survey Professional Paper, 252, $57 \mathrm{p}$.

Nordin, C.F., and Sabol, G.V., 1974, Emprirical data on longitudinal dispersion in rivers: U. S. Geological Survey Water-Resources Investigations Report 20-74, $108 \mathrm{p}$.

Turner, M.J., 1994, Data-collection methods and data summary for verification of a one-dimensional, unsteady-flow model of the Fox River in northeastern Illinois, October-November 1990: U.S. Geological Survey Open-File Report 93-483, 40 p.

Wilson, J.F., Jr., Cobb, Ernest D., and Kilpatrick, Frederick A., 1986, Fluorometric procedures for dye tracing: U.S. Geological Survey Techniques of Water-Resources Investigations, book 3, chap. A12, $41 \mathrm{p}$. 